OPEN ACCESS

Edited by:

Guillermo Booth-Rea, University of Granada, Spain

Reviewed by: Junpeng Wang, China University of Geosciences

Wuhan, China

Luigi Jovane,

University of São Paulo, Brazil

*Correspondence:

Xiwei Xu

Xiweixu@vip.sina.com

Specialty section:

This article was submitted to

Structural Geology and Tectonics,

a section of the journal

Frontiers in Earth Science

Received: 28 December 2020 Accepted: 17 February 2021

Published: 29 March 2021

Citation:

Bai L, Xu X, Luo H, Li K, Tan X and Zhao J (2021) Angular Unconformity of the Late Quaternary Strata in the Hetao Basin, North of the Ordos Block West China): Timing and Its

Tectonic Implications.

Front. Earth Sci. 9:646789. doi: 10.3389/feart.2021.646789

\section{Angular Unconformity of the Late Quaternary Strata in the Hetao Basin, North of the Ordos Block (West China): Timing and Its Tectonic Implications}

\author{
Luanxi Bai ${ }^{1}$, Xiwei $X u^{2 *}$, Hao $L u o^{3}$, Kang $L i^{2}$, Xibin $\operatorname{Tan}^{1}$ and Junxiang $Z \mathrm{Zhao}^{2}$ \\ ${ }^{1}$ State Key Laboratory of Earthquake Dynamics, Institute of Geology, China Earthquake Administration, Beijing, China, ${ }^{2}$ National \\ Institute of Natural Hazards, MEMC, Beijing, China, ${ }^{3}$ China Earthquake Disaster Prevention Center, China Earthquake \\ Administration, Beijing, China
}

Following the uplift of the Tibet Plateau and the continuous subduction of the Pacific Plate, graben faulting began to appear around the Ordos Block in the Cenozoic. The Hetao Basin is a Cenozoic rift basin between the Ordos Block and the Yinshan Mountains, and Late Quaternary sedimentary strata, which have lacustrine facies, are widely distributed inside this basin. However, the evolution of the Hetao Basin and its related fault systems has been debated for a long time due to the lack of tectonic evidence. In this study, four sections named Haolaigou, Bianqianghao, Huhesala, and Hazigai are selected along the north margin of the Hetao Basin. With the lithology and structural analysis of the Upper Pleistocene series in these sections, two new angular unconformities are found within the $10 \mathrm{~m}$ thick sedimentary sequence of the lacustrine sediments. Based on the dating results, we speculate that these two upper and lower angular unconformities are formed between $33 \mathrm{ka} \mathrm{BP}$ and $40 \mathrm{ka} \mathrm{BP}$, and $60 \mathrm{ka} \mathrm{BP}$ and $80 \mathrm{ka} \mathrm{BP}$, respectively. The angular unconformities also provide tectonic constraints for the latest and ongoing tectonic activity in the Quaternary. This tectonic movement begins at around $80 \mathrm{ka} \mathrm{BP}$ and causes two different unconformities of the lower strata with varying degrees of deformation (tilt) but also leads to the final death of the ancient lake.

Keywords: Hetao basin, angular unconformities, lacustrine sediments sections, dating, tectonic movement

\section{INTRODUCTION}

Located in the western part of the North China Craton, the Ordos Block was formed as a weak destruction zone following the destruction of the North China Carton since the Early Mesozoic (Figure 1) (Griffin et al., 1998; Menzies and Xu, 1998; Wu et al., 2005; Wu et al., 2008; Zhu and Zheng, 2009; He, 2015; Zhu, 2018). Previous studies have shown that the Ordos Block has experienced three-stage extensional deformation, which generated a series of rifted basins and normal fault systems around the Ordos Block. (The Research Group on Active Fault System around Ordos Massif, State Seismological Bureau (RGAFSO), 1988; Wan and Cao, 1992; Wan, 1994; Ren et al., 2002; Zhu, 2018). How these rifted basins and fault systems formed has been argued for a long time (Peltzer et al., 1985; Liu et al., 2004; Yin et al., 2010; Zhang et al., 2019). Two end models have been proposed: 1) rifting caused by the rollback of the Pacific subduction plate (Uyeda et al., 1979; Tian et al., 1992; Northrup et al., 1995; Schellart and Lister, 2005) and 2) anticlockwise rotation of the Ordos Block driven by eastward extrusion of the North-eastern Tibetan Plateau (Tapponnier et al., 


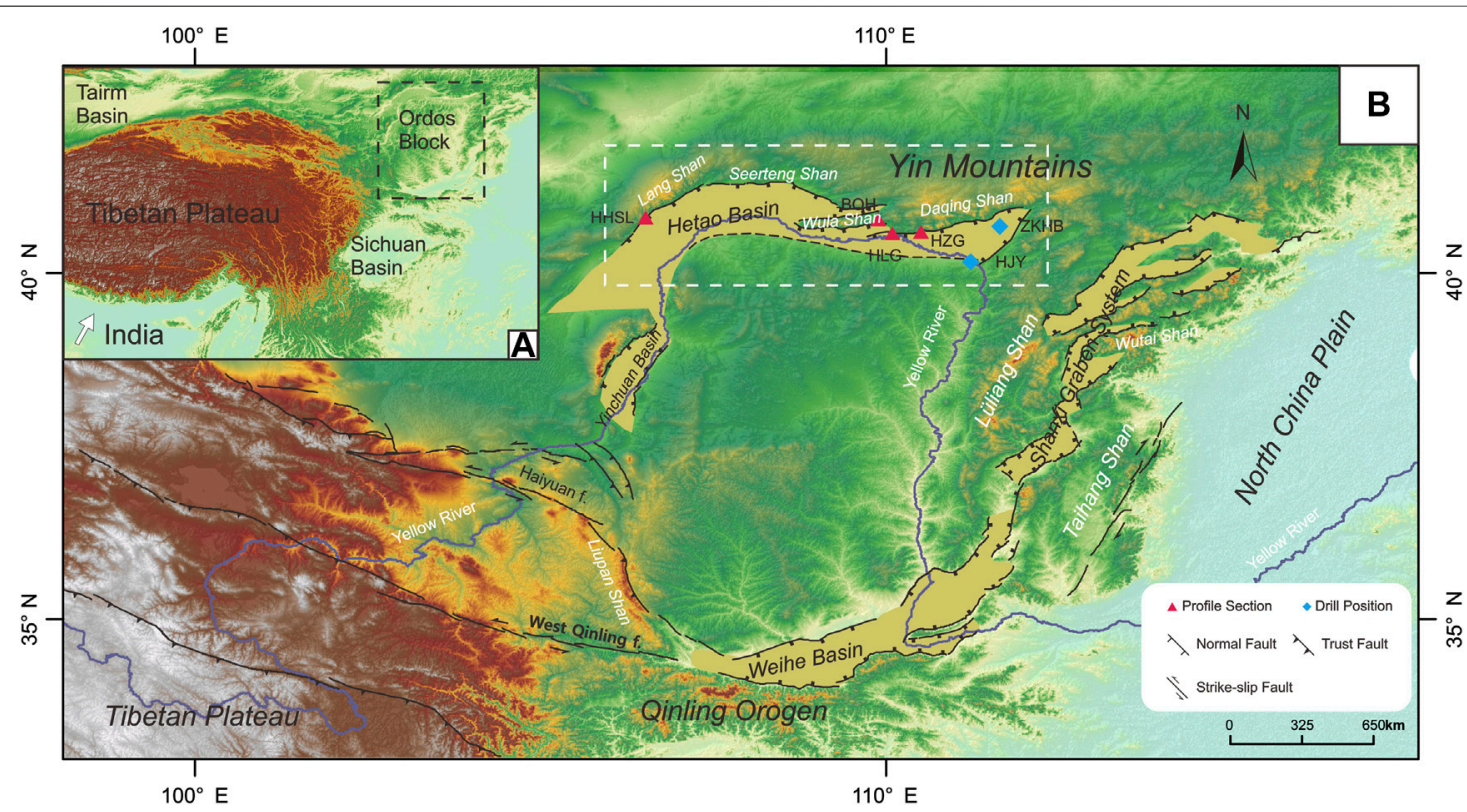

FIGURE 1 | (A) Location and topography of the graben systems around the Ordos Block adjacent to the northeast margin of the Tibetan Plateau (B) Tectonic pattern of the Ordos Block and its adjacent regions (modified from Deng et al., 2002). The dashed box denotes the study area. Yellow areas represent the rifted basins surrounding the Ordos Block, including the Yichuan-Jilantai and Hetao Basins to the west and north, Shanxi Graben to the east, and Weihe Basin to the south. DEM data originated from https://earthdata.nasa.gov/.

1982; Xu et al., 1992; Gaudemer et al., 1995; Zhang et al., 2018; Shi et al., 2020). The rifting model suggests normal faulting for the fault system around the Ordos, yet the rotational model may result in strike-slip movement. Thus, the strike-slip movement of the fault system could provide a chance to explore this issue.

Recently, plenty of evidence has shown that strike-slip movements exist in the periphery of the Ordos Block. Based on a detailed field investigation of fault geometry and its kinematics, Xu et al. (1992) proposed that the Ordos Block has experienced or is experiencing counter clockwise movement, which indicates a left-lateral strike-slip movement of the EW-trending faults and right-lateral movements of the NNE-trending faults. Furthermore, based on GPS observations in North China, Zhang et al. (2018) also suggested that N-Strending normal faults with dextral components may be formed by a rotational block model, in which the E-Wtrending structures, such as faults or shear zones, have a sinistral strike-slip movement. Additionally, focal mechanism solutions of earthquakes also suggest a strike-slip movement around the Ordos Block (Lin et al., 2017). Nevertheless, a lack of sedimentary evidence has prohibited the exploration of the timing of the onset of strike-slip activity.

In this study, we focused on the Hetao Rifted Basin to the north of the Ordos Block. As it acts as a paleolake during the last glacial-interglacial period (Li et al., 2007; Jia et al., 2016; Li et al., 2017; Cai et al., 2018), widely distributed lacustrine sediments of the Hetao paleolake could provide a sedimentary archive for recording the history of the evolution of the Hetao paleolake and its tectonics activity (Li et al., 2017; Cai et al., 2018; Yang et al., 2018, Yang et al., 2020). Based on a detailed investigation of the piedmont faults in the northern margin of the Hetao Basin, we documented a series of Late Quaternary angular unconformities within four sedimentary sections, including Hazigai, Haolaigou, Bianqianghao, and Huhesala. Combined with Quaternary dating of sediments and geological logging of these sections, we constrain the timing of these angular unconformities that indicate the latest tectonic movements. Based on the correlations among the timing of unconformities and the climate curves and regional deformation events, we discuss the potential formation mechanisms of the unconformities, their roles in explaining the causes of strike-slip activity, (e.g. local compression or transpression), and regional tectonic implications.

\section{REGIONAL SETTING}

The Ordos Block is a unique uplifted region with little interior deformation (Figure 1). The extensional Hetao Basin and Weihe Basin on the north and south sides of the Ordos Block were formed from the end of the Paleocene to the early Eocene. The extensional Yinchuan Basin, on the west side of the Ordos Block, was formed during the middle Miocene. The Shanxi Graben System on the east side of the Ordos Block was formed in the Pliocene. Among these basins, the Hetao and Weihe Basins are characterized by left-lateral shear, while the Yinchuan Basin and 

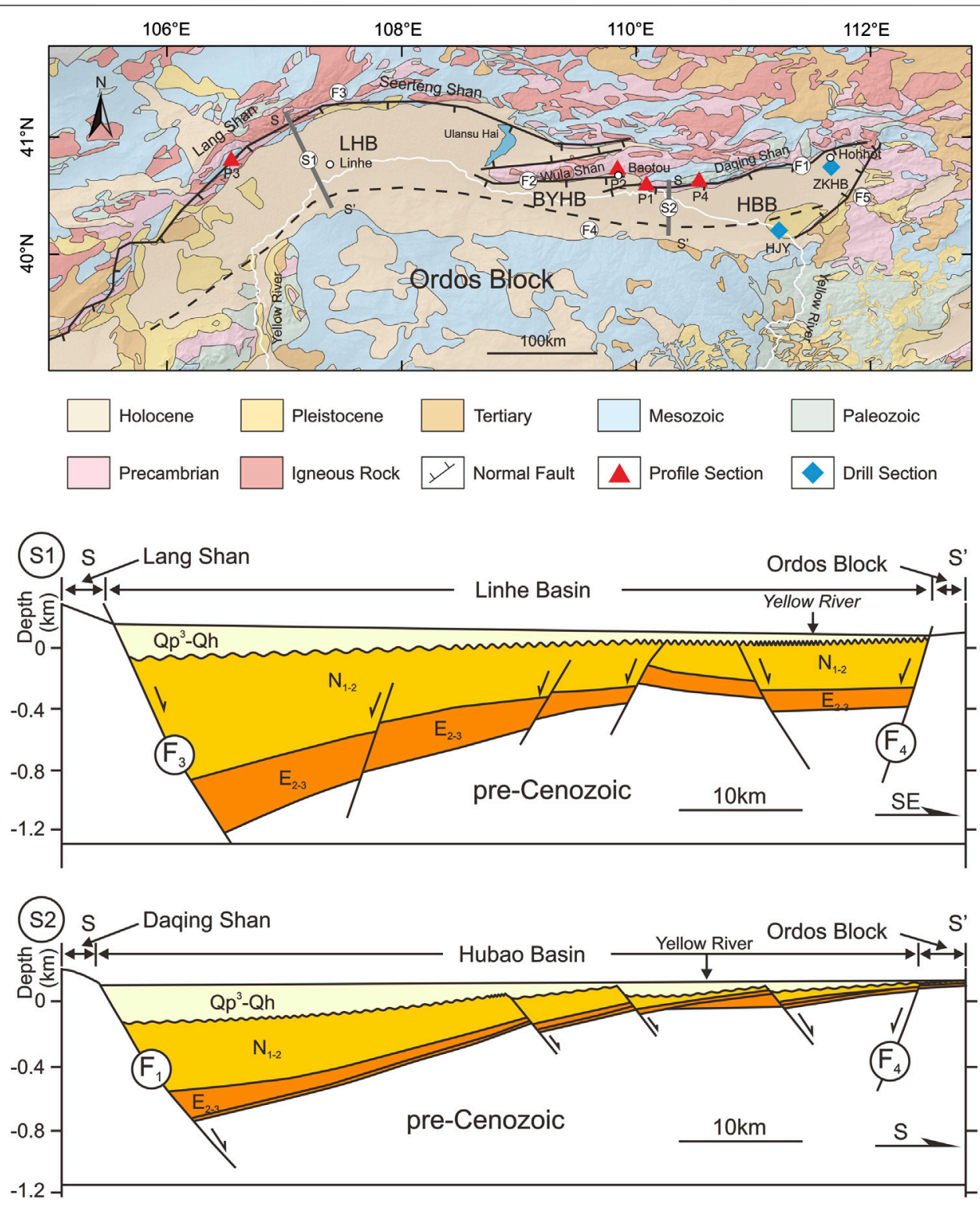

FIGURE 2 | Simplified geological map and Active faults distribution around the Hetao Basin (The Research Group on Active Fault System around Ordos Massif, State Seismological Bureau (RGAFSO), 1988). Structural section S1 and S2 modeled after Shi et al., 2020.

the Shanxi Graben system are characterized by right-lateral shear (The Research Group on Active Fault System around Ordos Massif, State Seismological Bureau (RGAFSO), 1988; Zhang et al., 1998; Shi et al., 2020). The north-eastward compression stress of the Ordos Block originates from the growth of the Tibetan Plateau to the southwest, the left-lateral of the fault zone in the northern margin of the Qinling Mountains and its eastward expansion; it is superimposed on the local uplift (Tapponnier et al., 1982; The Research Group on Active Fault System around Ordos Massif, State Seismological Bureau (RGAFSO), 1988; Xu et al., 1992; Northrup et al., 1995; He et al., 2017).

The Hetao Basin is located between the Ordos Block to the south and the Yinshan Mountains to the north. Geophysical data show that the Hetao Basin is a complex basin, separated from west to east by the Xishanju and Baotou sub-concealed uplifts, forming three secondary basins: the Linhe Basin, Baiyanhua Basin, and Hubao Basin. The basic shape of these sub-basins is a dustpan that is deep in the north and shallow in the south, which are controlled by the Langshan-Seertengshan Piedmont Fault, the Wulashan Piedmont Fault, and the Daqingshan Piedmont Fault (Figure 2) (The Research Group on Active Fault System around Ordos Massif, State Seismological Bureau (RGAFSO), 1988).

The red triangles denote the sediment sections in this paper. P1: Haolaigou Section; P2: Bianqianghao Section; P3: Huhesala Section; P4: Hazigai Section.

F1: Daqingshan Fault; F2: Wlashan Fault; F3: LangshanSeertengshan Fault; F4: North Ordos Fault; F5: Helingeer Fault. 
TABLE 1 | Results from the ${ }^{14} \mathrm{C}$ dating of samples HZG-05 and HZG-19 collected in Hazigai profile.

\begin{tabular}{|c|c|c|c|c|}
\hline Sample code & Laboratory code & Measured radiocarbon age & Isotopes results o/oo & $\begin{array}{l}\text { Conventional radiocarbon age } \\
\qquad\left({ }^{*}\right)\end{array}$ \\
\hline HZG-05 & Beta-444786 & $27,270 \pm 120 \mathrm{BP}$ & $\mathrm{d} 13 \mathrm{C}=-26.1$ & $27,250 \pm 120 \mathrm{BP}$ \\
\hline HZG-19 & Beta-444790 & $14,610 \pm 70 \mathrm{BP}$ & $d 13 C=-22.4$ & $14,650 \pm 70 \mathrm{BP}$ \\
\hline
\end{tabular}

\section{METHODS}

\section{Documenting the Geological Characteristics of the Sedimentary Sections}

Four representative sedimentary exposures on the northern margin of the Hetao Basin were documented in this study. Their locations are shown in Figure 2. Relations between the section and active fault traces, (e.g. hanging wall or footwall) are recorded based on field observations and Google Earth interpretations. The elevation of each section's top surface was measured using differential GPS. Detailed lithology, color, sedimentary structures, and facies have been documented in each section. The bedding dips were also measured to reveal the tectonic relationships between different strata units.

\section{Quaternary Dating of Sediments}

Previous studies have reported that with lacustrine sequence in the northern Hetao Basin may have primarily formed after the middle Pleistocene (The Research Group on Active Fault System around Ordos Massif, State Seismological Bureau (RGAFSO), 1988). Thus, we adopted different dating methods to obtain the sediment ages according to their lithology. In the upper section of the Hazigai section, we collected two charcoal samples for ${ }^{14} \mathrm{C}$ dating. These were processed at the Beta Analytic Radiocarbon Dating Laboratory, United States, using ${ }^{14} \mathrm{C}$ accelerator mass spectrometry (AMS). The pre-treatment of the samples for AMS involved carefully isolating roots and macrofossils by sieving and removing carbonates by acid washing. The ${ }^{14} \mathrm{C}$ results are presented in Table $\mathbf{1 .}$

In other clay and sand layers, optically stimulated luminescence (OSL) dating and electron spin resonance (ESR) dating were also conducted. Eight OSL samples and two OSL samples were collected from the Huhesala and Bianqianghao sections, respectively. Sixteen ESR samples and four ESR samples were obtained from the Haolaigou and Hazigai sections.

The OSL samples were processed and dated in the Key Laboratory of Crustal Dynamics, Institute of Crustal Dynamics, China Earthquake Administration. The samples were pre-treated in the laboratory under the subdued red light, using $30 \% \mathrm{HCl}$ and $30 \% \mathrm{H}_{2} \mathrm{O}_{2}$ to remove carbonates and organic material. According to the Stokes' Law, fine-grained quartz particles with sizes of $4-11 \mu \mathrm{m}$ were sieved from six samples in the Huhesala section after fluorosilicate acid etching. Thus, the multiple-aliquot regenerative-dose protocol (SMAR) dating protocol was used to measure the equivalent doses of these fine-grained samples (Wang et al., 2005; Lu et al., 2007). In contrast, coarse-grained particles with sizes of 90-125 $\mu \mathrm{m}$ were sieved from the other two samples in the Huhesala section and all samples in Bianqianghao sections. Coarse-grained quartz was etched by immersion in hydrofluoric acid. The equivalence doses (De) of these samples were obtained using a single-aliquot regenerative dating protocol (Murry and Wintle, 2000, Murry and Wintle, 2003). The irradiation and OSL signals of all these samples were measured using an automatic measurement system of the Denmark Risoe DA-20-C/D OSL instrument. Based on the relationship between the environmental dose rate absorbed by quartz minerals and the content of uranium, thorium, and potassium in the environment, the environmental dose rate absorbed by each sample was calculated (Aitken, 1998). The OSL results are presented in Table 2.

All ESR samples were collected in the Electron Spin Resonance Dating Laboratory at the Key Laboratory of Earthquake Dynamics, Institute of Geology, China Earthquake Administration. These samples were measured before and after drying to determine the water content. Dries samples were separated to obtain particles of size from 125 to $200 \mathrm{~mm}$. Additionally, $30 \% \mathrm{H}_{2} \mathrm{O}_{2}$ was used to remove organic matter, and $40 \% \mathrm{HCl}$ was used to remove carbonates. After washing with distilled water, the samples were etched with $40 \%$ HF for about $40 \mathrm{~min}$ to remove feldspar gains and the irradiated edge of the grains. Magnetic minerals were removed by magnetic separation after being raised to neutral with distilled water. The dried samples were split into 10 aliquots of $100 \mathrm{mg}$ each. All aliquots were exposed to $a^{60} \mathrm{Co}$ irradiation field to receive various additional gamma doses. The dose rate was calculated from the concentrations of the $\mathrm{U}$, Th, and $\mathrm{K}$, and water content was taken into account for correcting the dose rate (Aitken and Alldred, 1972; Aitken, 1976). The ESR results are presented in Table 3.

\section{RESULTS}

\section{Geomorphological and Sedimentary Characteristics of Sedimentary Sections Haolaigou Section (P1)}

The Haolaigou section is located in the western part of the Daqingshan Piedmont Fault (P1 in Figure 2). The geographic coordinates of the section are $40^{\circ} 34^{\prime} 57.94^{\prime \prime} \mathrm{N}, 110^{\circ} 5^{\prime} 33.77^{\prime \prime} \mathrm{E}$, and the altitude is $1,063 \mathrm{~m}$. The section is about $9 \mathrm{~m}$ high, and the buried lower part prevents us from documenting the earlier sediment structure. The upper $6 \mathrm{~m}$ of the section is brownyellow, yellow-green silt and clay interbedded with an average dipping angle of $2.5^{\circ}$, indicating shallow lake and deep lacustrine sediments. The lower $4 \mathrm{~m}$ part is gray medium-coarse sand with a 
TABLE 2 | Results from the OSL dating of samples collected in Huhesala profile and Bianqianghao profile.

\begin{tabular}{|c|c|c|c|c|c|c|c|c|c|}
\hline $\begin{array}{l}\text { Profile } \\
\text { name }\end{array}$ & $\begin{array}{c}\text { Sample } \\
\text { code }\end{array}$ & Depth (m) & $U(\mu g / g)$ & Th $(\mu \mathrm{g} / \mathrm{g})$ & K (\%) & $\begin{array}{c}\text { Dose } \\
\text { rate } \\
\text { (Gy/Ka) }\end{array}$ & $\begin{array}{c}\text { Test } \\
\text { method }\end{array}$ & $\begin{array}{l}\text { Equivalent } \\
\text { dose (Gy) }\end{array}$ & $\begin{array}{c}\text { Age (ka } \\
\text { BP) }\end{array}$ \\
\hline \multirow[t]{8}{*}{ Huhesala } & OSL-1 & 7.50 & 3.81 & 9.46 & 3.34 & 5.98 & SMAR & $221.55 \pm 19.19$ & $37.06 \pm 4.90$ \\
\hline & OSL-3 & 6.50 & 3.24 & 14.70 & 2.45 & 5.41 & & $385.95 \pm 16.37$ & $71.29 \pm 7.74$ \\
\hline & OSL-7 & 3.70 & 2.50 & 12.40 & 3.05 & 5.55 & & $358.66 \pm 39.82$ & $64.68 \pm 9.66$ \\
\hline & OSL-11 & 2.60 & 2.77 & 11.50 & 2.36 & 4.86 & & $303.36 \pm 23.17$ & $62.44 \pm 7.86$ \\
\hline & OSL-13 & 1.70 & 2.97 & 10.20 & 2.51 & 4.97 & & $80.47 \pm 2.81$ & $16.19 \pm 1.71$ \\
\hline & OSL-15 & 0.50 & 2.45 & 11.00 & 2.18 & 4.56 & & $54.89 \pm 5.61$ & $12.05 \pm 1.72$ \\
\hline & OSL-5 & 5.00 & 1.92 & 10.60 & 3.66 & 4.81 & SAR & $299.61 \pm 20.31$ & $62.24 \pm 7.52$ \\
\hline & OSL-9 & 3.30 & 1.86 & 9.00 & 3.90 & 4.94 & & $274.72 \pm 19.77$ & $55.60 \pm 6.85$ \\
\hline \multirow[t]{2}{*}{ Bianqianghao } & $\mathrm{BQH}-1$ & 2.00 & 1.3 & 4.4 & 1.82 & 2.63 & SAR & $98.94 \pm 13.25$ & $37.66 \pm 5.83$ \\
\hline & $\mathrm{BQH}-3$ & 2.50 & 0.8 & 1.9 & 2.05 & 2.61 & & $122.15 \pm 13.61$ & $46.74 \pm 6.35$ \\
\hline
\end{tabular}

grey-white calcium slab layer, which contains a gravel layer. The average dipping angle was approximately $7^{\circ}$. The grain size gradually became coarser from the bottom to the top, suggesting shallow lake-shore deposits (Figure 3A). Based on the lithology and sedimentary structure characteristics, we divided the section into 10 layers. Detailed descriptions of the units are listed as follows from the bottom to the top.

(1) $\quad 0-0.80 \mathrm{~m}$ : brown clay sandy gravel, residual sloping layer, and gravel with certain rounding.

(2) 0.80-2.20 m: brown-yellow gravel-bearing silty clay, partially sandwiched with a lenticular gravel layer, and with a $20 \mathrm{~cm}$ gravel layer at the bottom, which is the accumulation of top-slope alluvial deposits and is in angular unconformity contact with the underlying lacustrine strata. The stratigraphic occurrence is $103^{\circ}$ $<0.5^{\circ}$.

(3) 2.20-2.79 m: yellow-brown and grey-green silty strips interlayer, each layer is about $4 \mathrm{~cm}$ thick, and $15 \mathrm{~cm}$ at the top is sandwiched with grey-white clay strips, which contains extremely thick shale strips.

(4) 2.79-4.88 m: brown-red, brown-yellow medium-fine sand, and off-white muddy strips interbedded, the muddy strips are 0.5 to $1 \mathrm{~cm}$ thick, and the stratum occurrence is $190^{\circ}<2.5^{\circ}$.

(5) 4.88-5.90 m: dark yellow-brown gravel-bearing silt fine sand and blue-grey clay silt fine sand interbedded, partially with gravel lens, top containing a calcium plate layer, and thickness of about $0.5 \mathrm{~cm}$.

(6) 5.90-6.28 m: in angular unconformity contact with the overlying strata, light grey-yellow gravel-containing medium-coarse sand, developed cross-bedding, containing calcareous bands (calcium slabs), with a continuous calcium slab at the bottom $2 \mathrm{~cm}$ thick.

(7) $6.28-6.92 \mathrm{~m}$ : the stratum dip is about $7^{\circ}$, the yellowbrown coarse sand layer with a thickness of 6-7 cm and the grey-white semi-cemented clay medium sand layer with a thickness of $1-2 \mathrm{~cm}$ are interbedded. At the bottom of this layer, the gravel content increased. The particle size is 0.2 to $2 \mathrm{~cm}$, the rounding is better, and the stratum occurrence is $116^{\circ}<8.5^{\circ}$.
(8) 6.92-7.40 m: yellow-brown medium-fine sand layer, with a gravel layer on the top and bottom, with a grain size of 0.5 to $2 \mathrm{~cm}$, well rounded. The gravels are mostly sub-circular, and the stratum occurrence is $183^{\circ}<6^{\circ}$.

(9) $7.40-7.83 \mathrm{~m}$, the upper part is an interlayer of yellowbrown medium-fine sand and blue-grey clay fine sand, and the lower part is earthy yellow sandy clay. At the bottom $7.72-7.77 \mathrm{~m}$, there is a layer of coarse sand and gravel, and the gravel is well rounded.

(10) Below $7.83 \mathrm{~m}$ : light gray medium-fine sand with calcium board with a thickness of about $1-3 \mathrm{~mm}$.

The section is composed of lacustrine deposits in the middle. Among them, layers five and six and layers two and three are angular unconformity contacts (named as uc1 and uc2) (Figure 4). Layer six and below are all inclined at an angle of $6-8^{\circ}$. The thickness of layer seven gradually increases to the south of the section, indicating that the strata are still being deposited during the regressive process. Layers five to three are continuous lacustrine deposits, where sediment grains gradually become finer. Layers two and one are mainly brown-yellow, brown clay with gravels, which pseudo-integrated in contact with the bottom strata. Except for the obvious lack of simultaneous stratigraphic accumulation between the upper and lower strata, the dip of the underlying Sarawusu Formation is greater than that of the overlying Chengchuan Formation. The dip of the Sarawusu Formation is about $7^{\circ}$, while the dip of the Chengchuan Formation is about $3^{\circ}$, reflecting that an obvious tectonic movement occurred during this period. There is also a short-term lack of sedimentary strata and changes in the dip of this unconformity. The dip angle of the lower strata of the unconformity is approximately $3^{\circ}$, while the upper strata are nearly horizontal (Figure 3A).

\section{Bianqianghao Section (P2)}

The Bianqianghao section is located at the footwall of the easternmost Wulashan Piedmont Fault (P2 in Figure 2). The geographic coordinates of the Bianqianghao section are $40^{\circ} 42^{\prime} 56.80^{\prime \prime} \mathrm{N}, 109^{\circ} 50^{\prime} 40.60^{\prime \prime} \mathrm{E}$, and the altitude is $1,130 \mathrm{~m}$. The exposed section is about $5 \mathrm{~m}$ high, and the buried lower part prevents us from documenting the earlier sediment 
TABLE 3 | Results from the ESR dating of samples collected in Haolaigou profile and Hazigai profile.

\begin{tabular}{|c|c|c|c|c|c|c|c|c|}
\hline $\begin{array}{l}\text { Sample I } \\
\text { code }\end{array}$ & $\begin{array}{l}\text { Depth } \\
\text { (m) }\end{array}$ & $\begin{array}{c}U \\
(\mu \mathrm{g} / \mathrm{g})\end{array}$ & Th $(\mu g / g)$ & $\begin{array}{l}\mathrm{K}_{2} \mathrm{O} \\
(\%)\end{array}$ & $\begin{array}{c}\text { Water } \\
\text { content }(\%)\end{array}$ & De (Gy) & $\begin{array}{c}\text { Dose } \\
\text { rate (Gy/ka) }\end{array}$ & $\begin{array}{l}\text { Age (ka } \\
\text { BP) }\end{array}$ \\
\hline HLG-01 & 0.5 & 2.26 & 12.4 & 2.04 & 3.1 & $90 \pm 9$ & 3.25 & $28 \pm 2.8$ \\
\hline HLG-02 & 0.95 & 2.15 & 11.7 & 1.92 & 5.9 & $84 \pm 17$ & 2.96 & $29 \pm 5.8$ \\
\hline HLG-03 & 1.20 & 2.39 & 13.5 & 1.72 & 3.6 & $100 \pm 20$ & 3.05 & $33 \pm 6.6$ \\
\hline HLG-04 & 1.60 & 2.16 & 9.66 & 1.93 & 2 & $136 \pm 27$ & 2.98 & $46 \pm 9.2$ \\
\hline HLG-05 & 2.10 & 2.45 & 9.59 & 2.04 & 1.5 & $121 \pm 24$ & 3.16 & $38 \pm 7.6$ \\
\hline HLG-06 & 2.30 & 2.37 & 9.69 & 2.31 & 2.1 & $92 \pm 18$ & 3.38 & $27 \pm 5.4$ \\
\hline HLG-07 & 2.78 & 2.37 & 11.2 & 2.05 & 1 & $133 \pm 27$ & 3.29 & $40 \pm 8.0$ \\
\hline HLG-08 & 3.15 & 2.33 & 10.5 & 2.25 & 1 & $169 \pm 34$ & 3.42 & $49 \pm 9.9$ \\
\hline HLG-09 & 3.70 & 2.36 & 9.75 & 2.21 & 1 & $180 \pm 24$ & 3.33 & $50 \pm 6.9$ \\
\hline HLG-10 & 4.10 & 2.29 & 11.5 & 2.36 & 2.8 & $184 \pm 33$ & 3.5 & $52 \pm 9.3$ \\
\hline HLG-11 & 4.60 & 2.58 & 10.7 & 2.2 & 2.95 & $171 \pm 34$ & 3.36 & $51 \pm 11$ \\
\hline HLG-12 & 5.05 & 2.29 & 10.2 & 2.21 & 2.7 & $190 \pm 44$ & 3.28 & $57 \pm 13$ \\
\hline HLG-13 & 5.15 & 2.27 & 10.3 & 2.5 & 5.26 & $98 \pm 20$ & 3.43 & $29 \pm 5.8$ \\
\hline HLG-14 & 5.83 & 2.29 & 10.7 & 2.39 & 4.5 & $199 \pm 25$ & 3.4 & $59 \pm 7.7$ \\
\hline HLG-15 & 5.93 & 2.61 & 22.3 & 2.11 & 1.1 & $291 \pm 58$ & 4.19 & $70 \pm 14$ \\
\hline HLG-16 & 6.45 & 4.23 & 41.3 & 1.75 & 0.4 & $446 \pm 90$ & 5.64 & $79 \pm 16$ \\
\hline HLG-17 & 6.85 & 2.8 & 36.9 & 1.48 & 0.5 & $407 \pm 81$ & 4.93 & $83 \pm 16.6$ \\
\hline HLG-18 & 7.25 & 2.85 & 17 & 1.61 & 0.4 & $346 \pm 104$ & 3.43 & $101 \pm 30$ \\
\hline HLG-19 & 7.90 & 3.48 & 28.4 & 1.75 & 0.4 & - & 4.54 & - \\
\hline HLG-20 & 8.55 & 2.29 & 22.5 & 1.95 & 0.9 & $537 \pm 167$ & 3.98 & $135 \pm 30$ \\
\hline HLG-21 & 9.07 & 1.6 & 9.96 & 2.28 & 0.8 & $462 \pm 46$ & 3.24 & $143 \pm 14$ \\
\hline HLG-22 & 9.5 & 1.94 & 16 & 2.24 & 3 & $761 \pm 182$ & 3.61 & $211 \pm 46$ \\
\hline HZG-01 & 6.80 & 22.5 & 9.24 & 2.27 & 0.9 & $287 \pm 55$ & 3.32 & $86 \pm 16$ \\
\hline HZG-02 & 6.45 & 2.42 & 10.5 & 2.33 & 7.6 & $215 \pm 43$ & 3.23 & $67 \pm 13$ \\
\hline HZG-03 & 5.43 & 2.16 & 9.96 & 2.15 & 1.59 & $172 \pm 34$ & 3.22 & $53 \pm 11$ \\
\hline HZG-04 & 5.09 & 3.04 & 8.32 & 2.02 & 0.53 & $129 \pm 14$ & 3.24 & $40 \pm 4.5$ \\
\hline
\end{tabular}

structure. The section is mainly lacustrine deposits and the top $1.5 \mathrm{~m}$ is covered by loess deposits. The lower $1-\mathrm{m}$ part is yellow medium-coarse sand with a yellow clay layer. The average dipping angle is approximately $31^{\circ}$, which indicates shallow lake-shore lake deposits. The middle $2.5 \mathrm{~m}$ is also grey-yellow clay and fine sand layer with horizontal bedding, which suggests deep lacustrine sediments (Figure 3B). Detailed descriptions of the units are listed as follows from the bottom to the top.

(1) 0-1.5 m: yellow loess overburden.

(2) 1.5-1.7 m: greyish-yellow coarse sand layer.

(3) 1.7-2.0 m: gravel layer with certain rounding.

(4) 2.0-2.4 m: grey-yellow clay layer with horizontal bedding.

(5) 2.4-2.5 m: middle sand layer with small gravel inside.

(6) 2.5-3.5 m: fine sand layer, gradually thicker downwards, and with gravel at the bottom.

(7) 3.5-4.0 m: gravel layer with a small amount of clay layer in between.

(8) Below $4.0 \mathrm{~m}$, the middle sand layer and the clay layer are interbedded, and they are in angular unconformity contact with the overlying strata. The stratigraphic occurrence is $135^{\circ}<31^{\circ}$.

The unconformity uc2 is located between layers seven and 8 . The lower part of the unconformity surface of the section is lacustrine deposits, mostly consisting of medium-coarse sand and clay layers, which are in angular unconformity contact with the upper lacustrine stratigraphic deposits, and the dip angle of the formation is approximately $31^{\circ}$ (Figure 3B). Moreover, the dip of the underlying Chengchuan Formation is approximately $31^{\circ}$, while the overlying Chengchuan Formation is nearly horizontal (Figure 3B).

\section{Huhesala Section (P3)}

The Huhesala Section (P3) is located in the western part of the Langshan piedmont fault (Figure 2 P3). The geographic coordinates of the Huhesala Section are $40^{\circ} 47^{\prime} 29.20^{\prime \prime} \mathrm{N}$, $106^{\circ} 32^{\prime} 59.40^{\prime \prime} \mathrm{E}$, and the altitude is $1,266 \mathrm{~m}$. The section is approximately $8 \mathrm{~m}$ high, and we cannot see the end of this section. The upper part of the unconformity of the section is a layer of gravel. The grain size in this section gradually becomes finer from top to bottom, and the top is a layer of sloping material that is stacked in disorder. The lower part of the section is a brown-yellow, grey-yellow silt layer and clay layer, which are shallow lake-shore lake deposits, and the stratum dip is $15^{\circ}$ (Figure 3C). According to the lithology and sedimentary structure characteristics, it is divided into 10 layers from bottom to top.

(1) 0-1.0 m: variegated clay layer.

(2) 1.0-1.8 m: greyish-yellow silt layer.

(3) $1.8-2.3 \mathrm{~m}$ : variegated clay layer.

(4) 2.3-3.0 m: greyish-yellow silt layer.

(5) 3.0-3.5 m: brown-red coarse sand layer, containing fine sand, and stratum occurrence $240^{\circ}<15^{\circ}$.

(6) 3.5-4.0 m: silt fine sand layer.

(7) 4.0-4.7 m: clay layer with silty sand layer, with horizontal bedding.

(8) 4.7-6.3 m: brown-yellow coarse sand layer with gravel. 

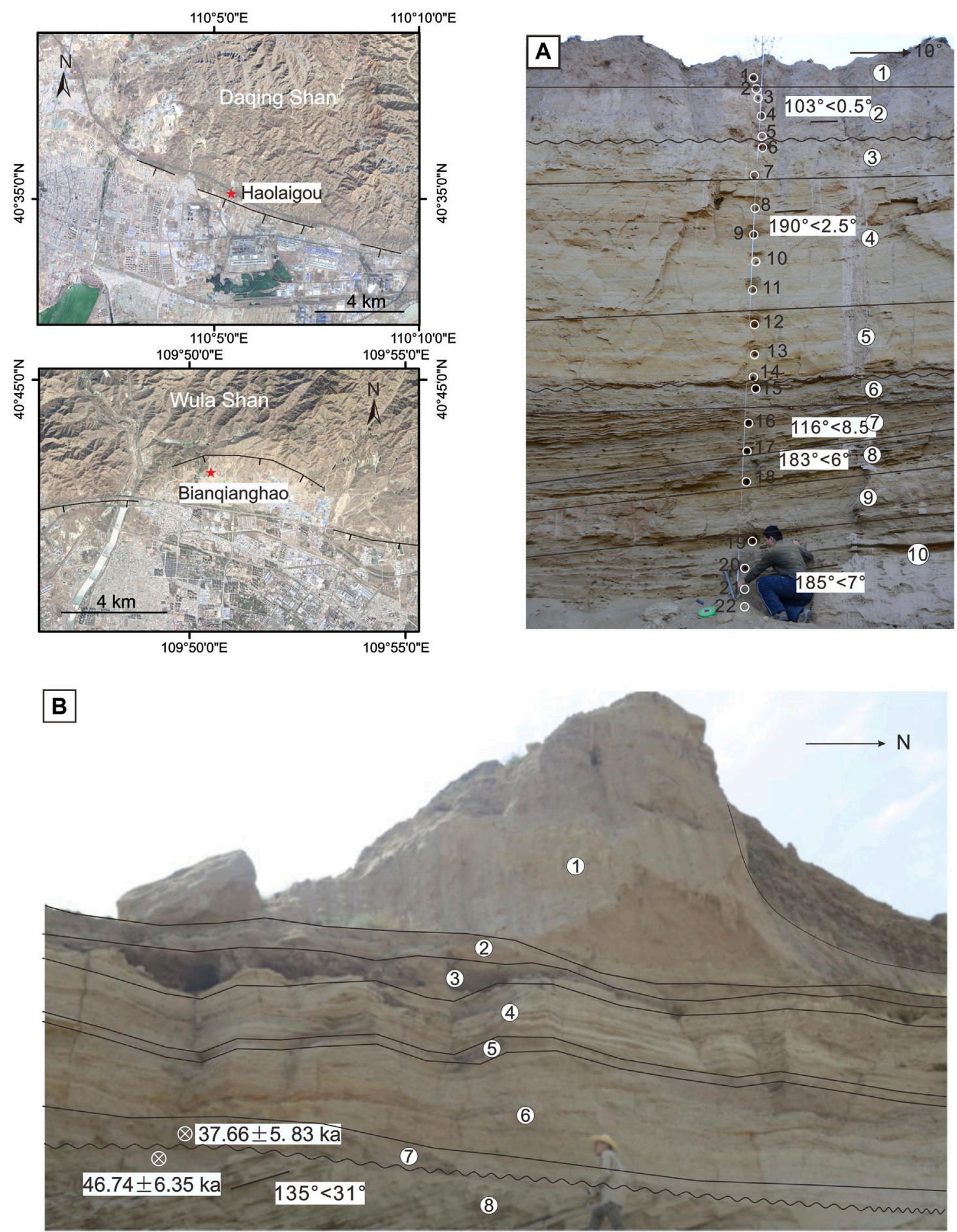

FIGURE 3 | Photos showing four sedimentary sections at Haolaigou (P1), Bianqianghao (P2), Huhusala (P3), and Hazigai (P4).

(9) 6.3-7.3 m: clay layer, with horizontal bedding, with a $15 \mathrm{~cm}$ thick silt sand layer in the middle, a thin layer of coarse sand on the top, and stratum occurrence $235^{\circ}$ $<11^{\circ}$.

(10) Below $7.3 \mathrm{~m}$ : greyish-yellow coarse sand.
The stratum as a whole is lacustrine strata sedimentation, with obvious tilt, and the exact position of the unconformity is not seen. It is assumed to be covered by the upper gravel collapse. No unconformity contact surface is seen in the Huhesala Section but according to the dating results, it is 

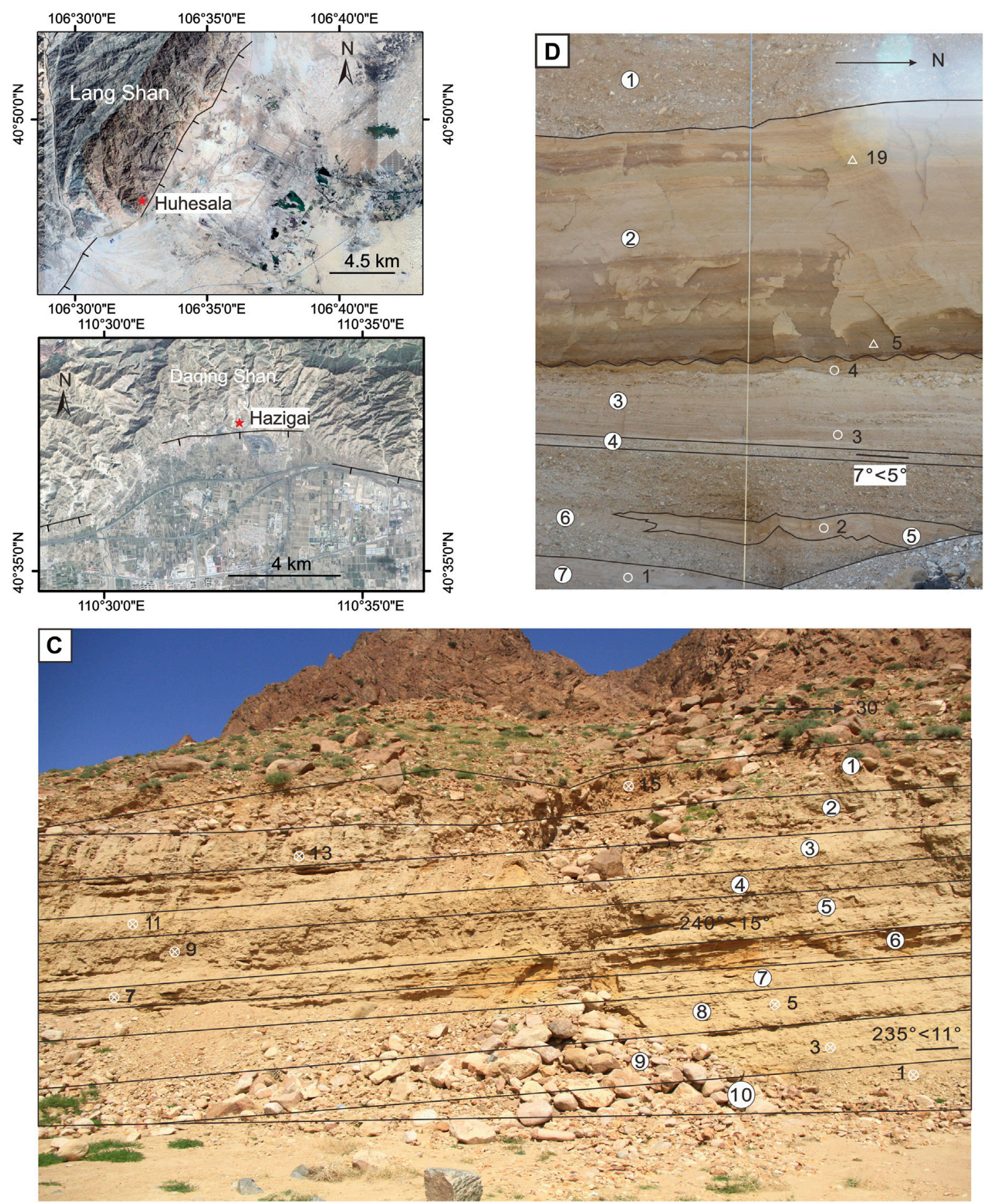

FIGURE 3 | (Continued).

inferred that the unconformity surface is near the buried depth of a $2 \mathrm{~m}$ section (uc2). The lower strata is a sloping stratum and the dip of the underlying is approximately $15^{\circ}$. The upper stratum is covered and the location of the horizontal gravel at the top of the section is presumed (Figure 3C). The unconformity is located in the Upper Pleistocene Chengchuan Formation.

\section{Hazigai Section (P4)}

The Hazigai Section is located in the middle part of the Daqingshan Piedmont Fault (Figure 2 P4). The geographic coordinates of the Haolaigou section are $40^{\circ} 37^{\prime} 6.15^{\prime \prime} \mathrm{N}$, $110^{\circ} 32^{\prime} 36.49^{\prime \prime} \mathrm{E}$, and the altitude is $1,053 \mathrm{~m}$. The section is approximately $7 \mathrm{~m}$ high and we cannot see the end of this section. The lower part of the surface is composed of 


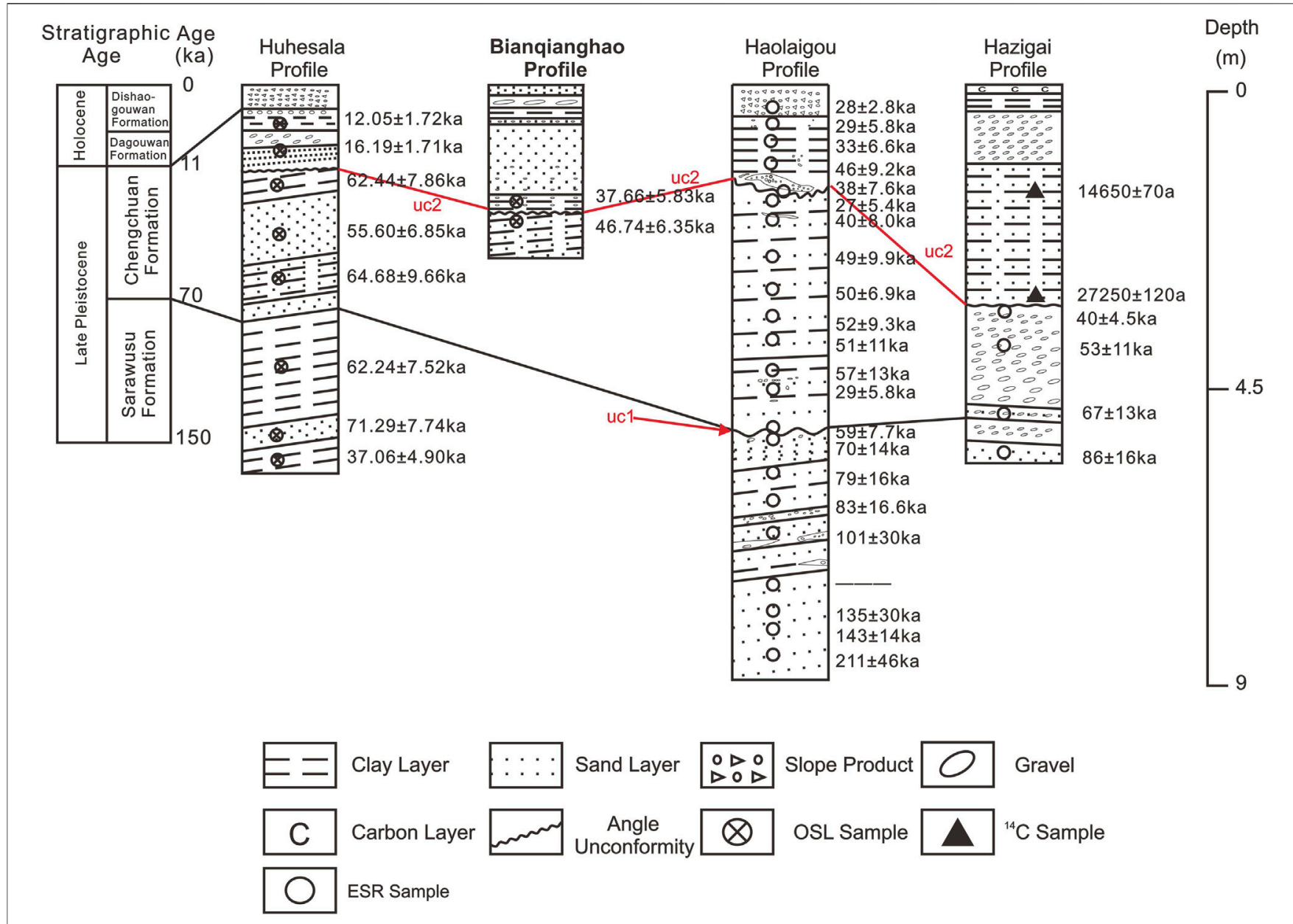

FIGURE 4 | Geological logging and correlations of four sections. The Quaternary stratigraphic chronology of the Sarawusu River area was constructed by Su et al. (1997).

lacustrine-fluvial deposits, mostly coarse sand and gravel deposits, with well-developed stratigraphic interruptions, which are in angular unconformity contact with the upper lacustrine stratigraphic deposits; the gravels are slightly oriented with a dip angle of approximately $5^{\circ}$ (Figure 3D). According to lithology and sedimentary structure characteristics, it is divided into seven layers from bottom to top.

(1) 0-1.0 m: mixed gravel accumulation layer.

(2) 1.0-4.5 m: grey-yellow silt layer with nearly level bedding.

(3) 4.5-5.5 m: small gravel layer, gravel size of approximately $2 \mathrm{~cm}$, sorting and rounding is suitable, there is a slight orientation, and there are large gravel clumps locally.

(4) 5.5-5.7 m: red-brown coarse sand layer, stratum occurrence $7^{\circ}<5^{\circ}$.

(5) 5.7-6.7 m: brown-yellow medium-coarse sand layer with a dip of about $5^{\circ}$, partially containing calcareous nodules.

(6) 6.2-6.5 m: gravel layer, the size of the gravel is about $3-5 \mathrm{~cm}$, the bottom is poorly rounded, and the gravel is slightly oriented.
(7) Below $6.7 \mathrm{~m}$ : light gray coarse sand layer with gravel.

There are obvious differences in lithology between the $2 / 3$ layers (uc2). Strata two is lacustrine facies stratum deposition, strata three is fluvial facies stratum deposition, the gravels in strata three and below are slightly oriented, and the sand layer is inclined. The stratum of the lower Chengchuan Formation is fluvial deposits with a dip angle of approximately $7^{\circ}$. The stratum of the overlying Chengchuan Formation is lacustrine deposits, and the stratum is nearly horizontal (Figure 3D).

\section{Dating Results of the Sediments}

Eight OSL samples were collected from the Huhesala section with ages ranging from $12 \mathrm{ka}$ to $71 \mathrm{ka}$ (Figure 4). All ages obey the normal sedimentary sequence except for the lower sample OSL-1, which was dated to be $37.06 \pm 4.90 \mathrm{ka}$. This outlier may be caused by the exposure of the sample. Comparing the lithology, facies, and dating results with that of the standard sedimentary strata of the Sarawusu Formation in North China (Sun et al., 1996), the upper layers one to seven in the Huhesala section composed of 
lacustrine strata corresponds to the upper part of the Late Pleistocene Chengchuan Formation (70-10 ka BP) in this region (Figure 4). The lower layers eight and nine consist of lacustrine strata accumulated before $79 \mathrm{ka} \mathrm{BP}$, which corresponds to the Late Pleistocene Sarawusu Formation (136-70 ka BP). It is the main accumulation strata of the Hetao ancient lake (Chadin et al., 1924; Sun et al., 1996; Su et al., 1997).

In the Haolaigou section, 22 ESR samples collected at a depth of 0.5 to $9 \mathrm{~m}$ were estimated to range from $28 \mathrm{ka}$ to $211 \mathrm{ka}$ (Figure 4). Except for two samples (HLG-5 and HLG-13) expressed as outlier ages, all other sample ages follow the normal sedimentation sequence. In this section, based on our dense age estimation, we suggest that layers 6 to 10 and two to five belong to the Sarawusu and Chengchuan formations, respectively. The upper unconformity was located between layers 2 and 3, inside the Chengchuan Formation, with an age range of $38-40 \mathrm{ka}$. The lower unconformity is located at the boundary of the Sarawusu and Chengchuan formations.

OSL samples BQH-1 and BQH-3 collected from Bianqianghao section were dated to be $37.06 \pm 4.90 \mathrm{ka}$ and $37.06 \pm 4.90 \mathrm{ka}$, respectively. A sedimentary gap at the age of $47-38 \mathrm{ka} \mathrm{BP}$ exists at the unconformity surface between the layers dated by these two samples. Similar sedimentation characteristics of layers two to three in the Haolaigou section suggest that this layer could belong to the Chengchuan Formation. The unconformity is located in the Upper Pleistocene Chengchuan Formation.

In the Hazigai section, two ${ }^{14} \mathrm{C}$ samples constrain the age of the upper silt sand layers to be $14.65-27.25 \mathrm{ka}$. The bottom four ESR samples were estimated to be $40-86 \mathrm{ka}$ within a normal sedimentary sequence. The unconformity in this section is located inside the Chengchuan Formation, and its timing of $27-40 \mathrm{ka} \mathrm{BP}$ is similar to that of the upper unconformity at the Haolaigou section. However, the strata above or belonging to the unconformity are both lacustrine deposits and fluvial sediments.

Collectively, we constrained two stages of unconformity in the Haolaigou section but only one in the other three sections. The upper and lower angular unconformities are speculated to be formed between $33 \mathrm{ka} \mathrm{BP}$ and $40 \mathrm{ka} \mathrm{BP}$, and $60 \mathrm{ka} \mathrm{BP}$ and $80 \mathrm{ka}$ $\mathrm{BP}$, respectively. The timings of the angular unconformities in the Bianqianghao, Huhesala, and Hazigai sections were 38-47 ka BP, 16-62 ka BP, and $27.25 \mathrm{ka}-40 \mathrm{ka} \mathrm{BP}$, respectively.

\section{DISCUSSION}

\section{Quaternary Strata Framework in the Hetao Basin and Reliability of Our Dating Ages}

Determining the timing of the unconformity requires us to understand the stratigraphic framework, its continuity and age. Our sedimentary section mostly deposits from $\sim 150 \mathrm{ka}$ to $\sim 12 \mathrm{ka}$, which corresponds to the period of the Sarawusu and Chengchuan formations. Only one ESR sample in the Haolaigou section was $211 \pm 46 \mathrm{ka}$, which may belong to the Nihewan Formation. In order to more reasonably determine the stratigraphic age of the Hetao Basin, we will compare the facies and ages of sediments in our section with the Late
Pleistocene standard stratigraphic section of the Sarawusu and Chengchuan formations in this region.

The Sarawusu Formation corresponds to layers 10 and nine in the Huhesala section, Layers 15 to 18 in the Haolaigou section, and layers eight to nine in the Hazigai section. These layers mainly consist of clay, silt sand, and local gravels, indicating lacustrine facies, which is consistent with that in the standard Sarawusu Formation, as suggested by the palynological analysis (Yuan, 1978). In this region, deposits accumulated under mild and humid climates. Previous dating results suggested that the Sarawusu Formation was formed during the last interglacial period at 136-70 ka BP, corresponding to MIS5. Thus, based on the ages and sediment facies, we suggest that the Sarawusu Formation is continuous in our section, as least in the Haolaigou section.

The standard Chengchuan Formation is a fluvial facies or aeolian sand, indicating a dry and cold climate environment, but short with mild and humid stages (Yuan, 1978). Studies on organic matter content, particle size, and carbonate isotopes show that the Sarawusu Formation has higher organic matter content and finer particle size than those of the Chengchuan Formation (Sun et al., 1996; Li et al., 2001; Zhang et al., 2001). Relatively enriched $\mathrm{CaCO}_{3}$ in the Chengchuan Formation represents a humid period (Luo et al., 2002). The Chengchuan Formation formed during the last glacial period at approximately $70-10 \mathrm{ka}$ BP. In our sections, the Chengchuan Formation is very continuous, as in the Huhesala and Haolaigpou sections. The deposited sediments are also consistent with the standard Chengchuan Formation (Yuan, 1978).

Additionally, seven boreholes were drilled in the Yinchuan Basin and revealed the stratum from the Lower Pleistocene to the Upper Pleistocene (Tong et al., 1995; Yang et al., 2001). As there is no obvious geomorphic boundary between the Hetao and Yinchuan Basins, the two currently connected basins may have similar sedimentary evolution characteristics and lithological combinations (Tong et al., 1998). Recent research shows that the lacustrine strata in the Yangyuan Basin are continuously deposited (Yuan et al., 1996; Min et al., 2000).

The detailed lithology description of the stratigraphic section and systematic chronological test analysis of stratigraphic samples shown that the strata in this study area are mainly the Upper Pleistocene Sarawusu and Chengchuan formation (Figure 4).

\section{Potential Drivers for the Formation of the Late Quaternary Unconformities in the Hetao Basin}

Unconformities record tectonic movements or sea-(lake) level change events or paleoclimate changes (He, 2007; Ali and Farid, 2016; Liu, 2016; Hicks and Green, 2017). The generation of angular unconformity with underlying plastic strata reflects the one-stage cyclic process from subsidence, deposition to uplift, erosion or no deposition, to subsidence and deposition, and is generally regarded as the result of tectonic events and strata uplift (Lin et al., 2008; He et al., 2011, He et al., 2015). 


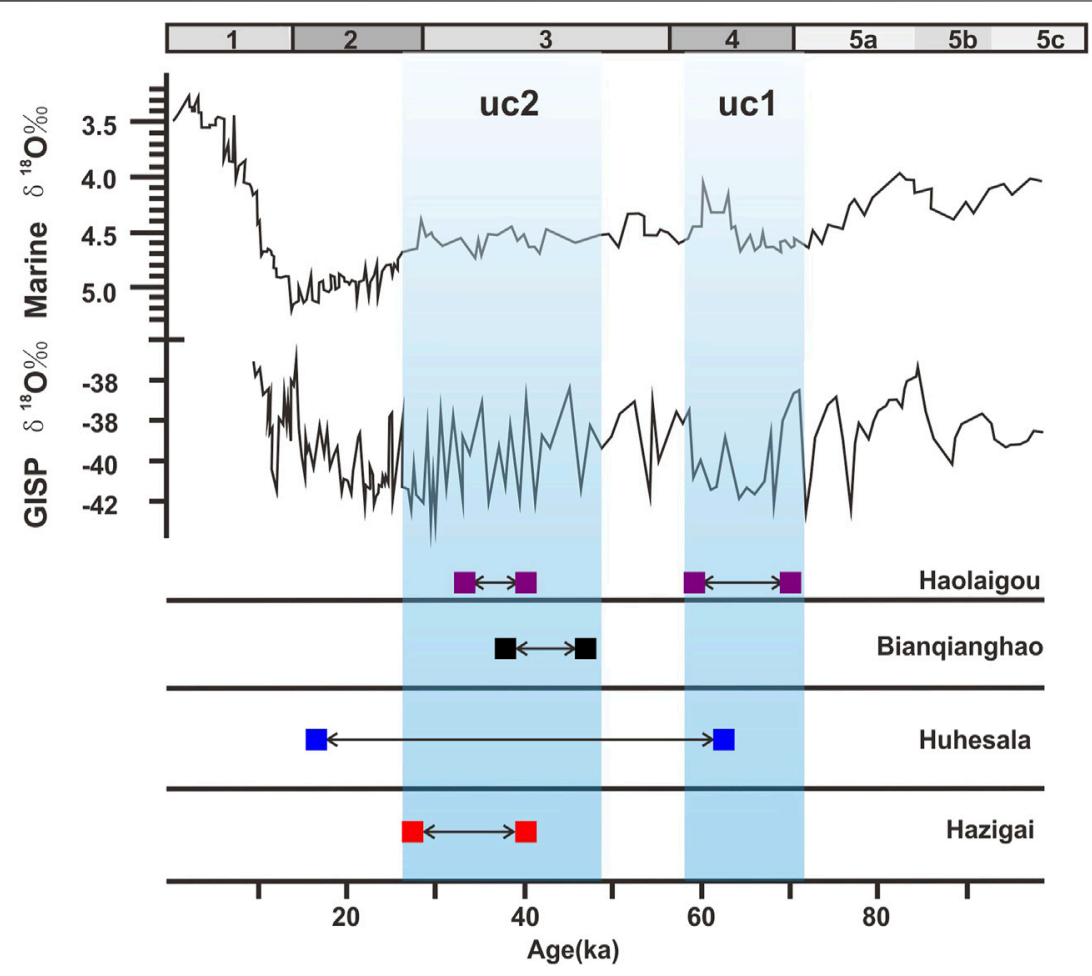

FIGURE 5 | Correlations between the timing of unconformities derived from four sedimentary sections and climatic change curves during the Late Quaternary. Marine oxygen isotope curve and (GISP) are from Shackleton et al. (1983) and Yao (1999), respectively. Light blue regions show the interval of the sedimentation (uc1 and uc2).

Two stages of angular unconformities were discovered at the northern edge of the Hetao Basin. Chronological constraints of the sediments below or above the unconformity surface suggest that the discontinuity time of the deposition is short. The earlier unconformity surface (uc1) of the Haolaigou section is a sedimentary discontinuity between the Sarawusu and Chengchuan formations. However, the late unconformities (uc2) in the Huhesala, Bianqianghao, and Hazigai sections appeared within the Chengchuan Formation.

\section{Climate Changes}

As all sections are located at the margin of the basin and due to the low-dipping angle of layers at each side of the unconformities (such as ucl in Haolaigou and Hazigai sections), the retreatprogress sequence may result in the formation of unconformities. The Hetao Basin is located in the Inner Mongolia, northern China. And this area is along the margin of the East Asian monsoon region. So, the area is sensitive to climatic changes, which may be reflected in the strata deposition break. In this scenario, the bottom sediments underlying the unconformities will show a cold-dry climate, whereas the upper strata will show a warm and humid climate. The unconformities were formed during the transition from cold to warm climate (Figure 5). Thus, to discern the relationship between the unconformities and climatic changes, we correlated its timing with oxygen isotope curves (Figure 5).
In Figure 5, ucl and uc2 are formed during marine isotope stages MIS4 and MIS3. The strata below ucl in the Hazigai accumulated at MIS 5a, when the climate is warm and humid. The above sediments were deposited at the transition of MIS four to MIS 3. Additionally, the timing for the formation of uc2 occurs during MIS3 or the transition from MIS $3 \mathrm{~b}$ to $3 \mathrm{a}$. During this period, the climate changed from warm and humid to cold and dry conditions, which contradicts the climate-driven mechanism.

On the other hand, if the unconformities were derived from climate change, the deposits within the basin or far from the basin margin will not show unconformities at the climate transition. Thus, we compiled the results of two cores within the Hetao Basin (Figures 2, 6).

Borehole ZKHB located in the north of the Tuoketuo platform shows an unconformity at a depth of $64.22 \mathrm{~m}$ formed during $271 \pm 40-108.7 \pm 7.8 \mathrm{ka} \mathrm{BP}$ (Li et al., 2007). The lithology of the strata below the unconformity surface is gravel, mixed sand, coarse sand-fine sand, silt sand, clay-gravel, mixed sand, and coarse sand, which reflects the lakeside-shallow lakeside lake face. Borehole HJY located at the front edge of the Tuoketuo platform also shows an unconformity at $12.77 \mathrm{~m}$ with a timing range from $116 \pm 4.7 \mathrm{ka}$ BP to $80.7 \pm 4.2 \mathrm{ka} \mathrm{BP}$ (Jiang et al., 2013). The top stratum is brown-yellow silty clay and clayey silt, which is aeolian loess accumulation. The lower lacustrine sediments consist of pale yellow-green-grey-brown powder-fine sand and silt clay. Collectively, these two unconformities formed at the center of the basin may occur during the climate transition from warm to dry. 


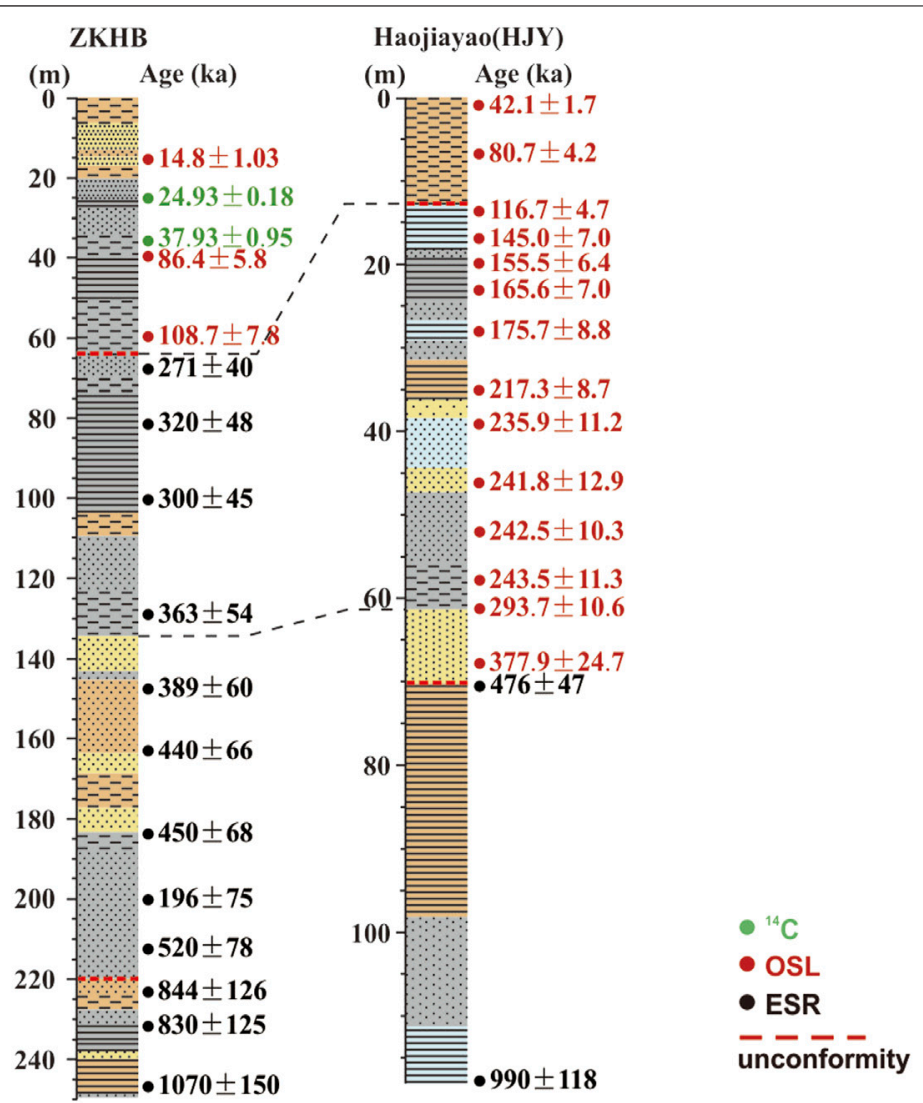

yellowsih-greyish sand-gravel

yellowish sand

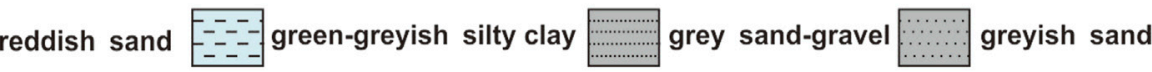

reddish clay

FIGURE 6 | Correlations of two drilling cores in the Hetao Basin based on the lithology and dating ages. Borehole locations are shown in Figure 2. The lithology and ages for these cores are from Jianbiao Li et al. (2007) (ZKHB) and Jiang et al. (2013) (HJY).

The formation time of the unconformities in our study appear to coincide with the glacial-interglacial transition periods. During warm stages, stream flows are increased, and lake deposits are continued. While, at the cold stages, the stream flows were reduced, and the lacustrine sedimentation was discontinued. The above evidence indicates that climate change is not the major factor in the formation of these unconformities.

\section{Tectonic Activity}

Studies on active faults and paleo-earthquakes have shown that the series of faults controlling the Hetao Basin are all PleistoceneHolocene active faults. There are multiple mid-late Pleistocene step landforms along the piedmont zone (Wu et al., 1996). Furthermore, the paleo-seismic studies revealed multiple ancient seismic events (Ran et al., 2003; He et al., 2015). Drilling data in the Hetao Basin reveals that the maximum deposition thickness of the basin since the Quaternary is $>2400 \mathrm{~m}$, and the conversion of river-lacustrine deposition to aeolian deposition has occurred in multiple stages (Li et al., 2017). Previous authors based on thermochronology, regional stratigraphy, and structural geomorphology have shown that the mountains to the north of the Hetao Basin and the subsiding basins have experienced multiple periods of tectonic uplift, erosion and flattening. Their tectonic uplift mode suggests tectonic tilt of the rising faults footwall. (The Research Group on Active Fault System around Ordos Massif, State Seismological Bureau (RGAFSO), 1988; Cheng et al., 2000; Wu and Wu, 2003).

The Haolaigou and Hazigai sections are located in the footwall of the Daqingshan Fault. The Huhesala section is located in the footwall of the Langshan Fault. Meanwhile, the Bianqianghao section is located in the hanging wall of the Wulashan Fault (Figure 7). The vertical sliding rate of the Daqingshan Fault zone has been $1.16-1.78 \mathrm{~mm} / \mathrm{a}$ in $100 \mathrm{ka}, 1.84-2.16 \mathrm{~mm} / \mathrm{a}$ in $24 \mathrm{ka}$, 0.34-1.72 mm/a in the Holocene (Wu et al., 1996; Li et al., 2007). The vertical sliding rate of the Wulashan Fault zone has been $1.38-1.80 \mathrm{~mm} / \mathrm{a}$ in $100 \mathrm{ka}, 0.16-1.92 \mathrm{~mm} / \mathrm{a}$ in $24 \mathrm{ka}$, and 

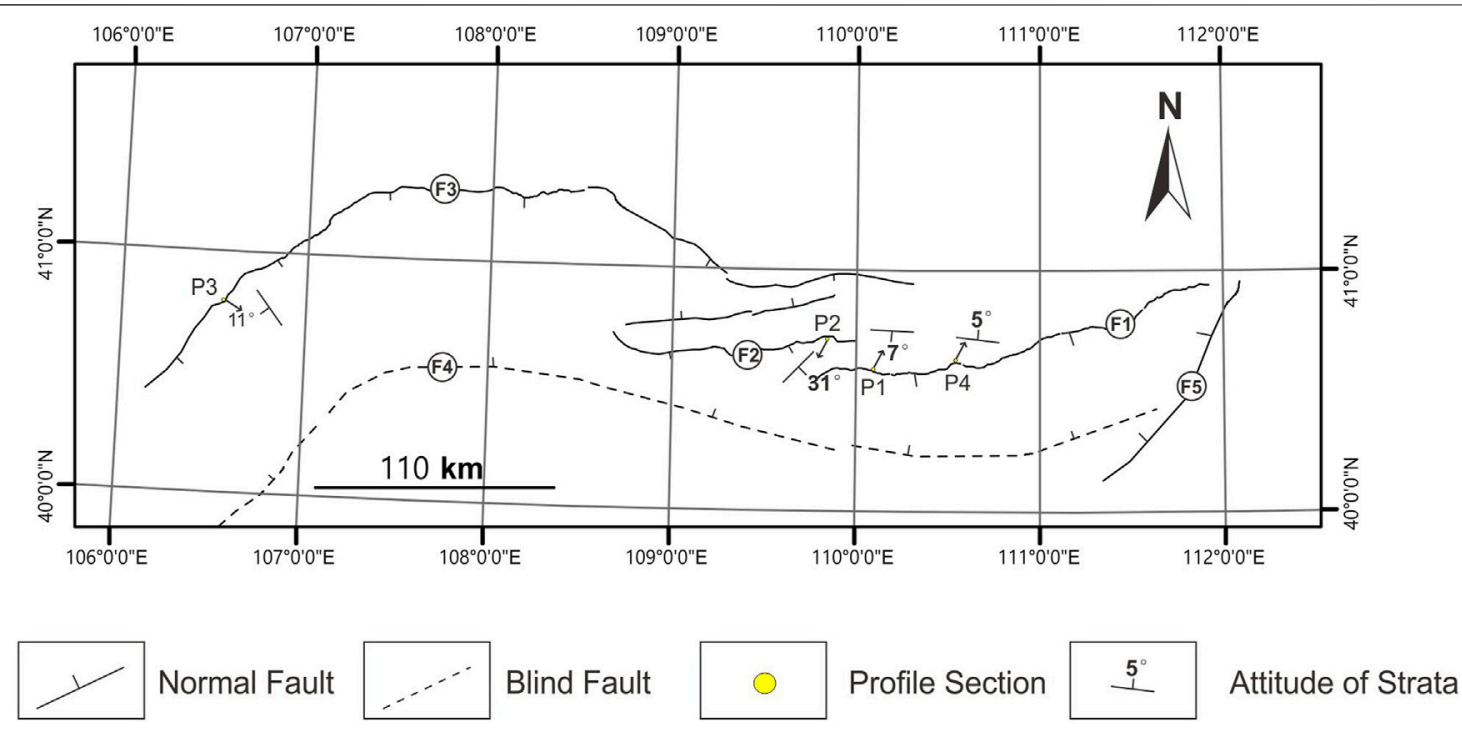

FIGURE 7 | The position of the study section and the fault. P1: Haolaigou Section; P2: Bianqianghao Section; P3: Huhesala Section; P4: Hazigai Section. F1: Daqingshan Fault; F2: Wlashan Fault; F3: Langshan-Seertengshan Fault; F4: North Ordos Fault; F5: Helingeer Fault. The attitude of strata marked on above is the attitude of the deformed strata below the unconformity surface. The attitude of P1 is the formation transition below uc1.

0.55-0.77 mm/a in the Holocene (Li et al., 2007). Research on the slip rate of the Langshan Fault scarce. But existing research results show that the maximum uplift rate of the footwall is $3.6 \mathrm{~mm} / \mathrm{a}$ since the end of the late Pleistocene. The maximum vertical sliding rate is $2.2 \mathrm{~mm} / \mathrm{a}$ in the Holocene (Wu et al., 1996). In addition, due to the counterclockwise rotation of the Ordos Block, left-handed strike-slip motions occurred in the eastwest-trending faults at the periphery (Xu et al., 1992; Zhang et al., 2018; Shi et al., 2020). Therefore, after the deposition of the lacustrine strata, along with the enhancement of the fault activity, the tilting movement of the footwall of the fault continued to occur, which eventually led to the deformation of the lacustrine stratigraphic deposits since the late Pleistocene. That is the formation of the unconformities we found in the Hetao Basin.

The angular unconformity in a specific geological area is an important basis for determining the evolution stage of the regional crustal structure (Wan, 2011). The dipping angle of the lower strata underneath the angular unconformities gradually decreased from west to east, and gradually became a parallel unconformity contact in the eastern edge of the Hetao Basin. Therefore, the formation of the angular unconformity is mostly related to tectonic activity. Additionally, river terraces $\mathrm{T} 4$ to $\mathrm{T} 1$ in the Langshan area west of our sections suggested four stages of incision at $58.00-51.61,46.25-41.28,32.19-23.22$, and $15.79 \mathrm{ka} \mathrm{BP}$ to present, respectively (Jia et al., 2015). The formation of the fourth-level river terraces is the result of the combined effects of climate change and tectonic movement (Jia et al., 2015, Jia et al., 2016). This time corresponds to the formation of the unconformity in the Hetao Basin. It suggests that the unconformity may be generated by the mountain uplift in the north Hetao Basin, leading to the exposure of the edge of the Hetao paleo-lake. Therefore, we suggest that the formation of unconformities in the northern Hetao Basin may be affected by climatic changes, but mainly controlled by tectonic movement.

\section{Regional Issues of the Tectonic Movement Found in the Northern Hetao Basin}

The unconformity that appeared at the northern margin of the Hetao Basin represents this tectonic movement that affected the Ordos block and its periphery. The lacustrine stratigraphic profile of the Tuoketuo platform in the southeast of the Hetao Basin also shows that the loess layer with a thickness of about $2.6 \mathrm{~m}$ and an accumulation of about $82 \mathrm{ka}$, containing calcareous nodules the underlying Sarawusu Formation and the overlying Chengchuan Formation all present an angular unconformity contact (Li et al., 2007), and the loess accumulation itself reflects the lack of sedimentary strata between the Sarawusu Formation and the Chengchuan Formation. The ancient Nihewan lake completely disappeared in the early Late Pleistocene (about $130 \mathrm{ka}$ ). $130-70 \mathrm{ka}$ is a sedimentary intermittent period that represents the uplift and erosion stage of the lake basin. It is covered by the late Pleistocene Malan loess and paleosol (47-19 ka) (Min et al., 2006). The fault activity in the Weihe Basin on the southern margin of the Ordos block reflects the existence of a strong fault and the formation of an angular unconformity about $120 \mathrm{ka}$ ago (Tian et al., 2003). In addition, the formation time of the unconformities we found in the Hetao Basin coincides in time with the uplift rate changes of the Ordos Block region since the formation of the $76.4 \mathrm{ka} \mathrm{BP}$ wide valley terraces in the Jinshan Gorge section of the Yellow River, from less than $0.23 \mathrm{~mm} / \mathrm{a}$ to more than $0.77 \mathrm{~mm} / \mathrm{a}$ (Cheng et al., 1998). This period of intense land-making and uplift is reflected by the Late Pleistocene uplifting period shown by the T3 terrace of the Yellow River 
near Linxia and the T3 terrace of the Xining to Huzhu section of the Huangshui River (the second tributary of the Yellow River) in the eastern margin of the Qinghai-Tibet Plateau (Li et al., 1996; Lu et al., 2004). Although, the above mentioned Late Pleistocene tectonic events have a certain time gap, it can be considered that the tectonic movement discovered in the northern Hetao Basin since the mid-late Pleistocene is not local, but is widely distributed in the North China Craton, that is, this tectonic movement has the basic characteristics of regional tectonic movement, and its manifestations are also diverse.

Furthermore, the NNE trending system of the Shanxi faulted basin belt shows right-lateral strike-slip movement, including the Xizhoushan West Foot Fault, Huoshan Piedmont Fault, Helanshan East Foot Fault, Yellow River Fault, Luoshan Fault, etc. The lefthanded strike-slip movement from the NWW toward the Daqingshan piedmont fault, Tieluzi fault, Cixian-Daming fault, Zhangjiakou-Penglai fault zone, etc. (Xu et al., 1993; Jiang and Zhang, 1997; Middleton et al., 2016), and a series of spade-shaped faults in the North China Plain during the middle and late Middle Pleistocene to the early late Pleistocene, and most of the seismogenic faults of historical major earthquakes in the North China Plain are NNE-NE and NWW-NW-trending new strike-slip faults (Xu et al., 2015). They may be closely related to the tectonic movement discovered in the Hetao Basin. Therefore, the tectonic movement represented by the series of angular unconformities discovered in the northern margin of the Hetao Basin is the latest tectonic movement since the mid-late Pleistocene of the North China Craton destruction zone.

Therefore, the latest tectonic movement in the Hetao Basin began in the early and mid-late Pleistocene ca. $80 \mathrm{ka}$. It is the result of the joint effect of the westward subduction of the Pacific Plate and the Philippine Sea Plate, the uplift of the material in the northeastern part of the Qinghai-Tibet Plateau, and the acceleration of the NE direction slip on the North China region. This reflects the same tectonic stress field consistent with the current GPS velocity field and focal mechanism solution. The Ordos Block and its surrounding area are affected by regional NE-SW principal compressive stress and NW-SE advocating stress. Specifically, the Shanxi and Yinchuan Basins on the east and west sides are right-handed oblique shear transtensional zones, while the Weihe and Hetao Basins on the north and south sides are left-handed shear extensional zones (Xu et al., 1992; Zhang et al., 2006, 2018, 2019; Cui et al., 2016; Shi et al., 2020).

\section{CONCLUSION}

(1) Analysis of the lithology and structure of the four Upper Pleistocene stratigraphic sections of the Hetao Basin shows that multiple angular unconformity events have

\section{REFERENCES}

Aitken, M. J., and Alldred, J. C. (1972). The assessment of error limits in thermoluminescent dating. Archaeometry, 14 (2), 257-267. doi:10.1111/j.1475-4754.1972.tb00068.x been recorded in lacustrine strata with a thickness of nearly $10 \mathrm{~m}$. The tectonic movements they represent occurred during the Late Pleistocene ( $80 \mathrm{ka} \mathrm{BP}$ ).

(2) The unconformities may be widely distributed in North China and may be the direct products of the latest Quaternary and ongoing tectonic movements. This tectonic activity not only caused varying degrees of deformation in the lower strata of the unconformity but also led to the eventual demise of the ancient Hetao lake in the Hetao Basin. The rapid regional land lifting movement of the Ordos Block since $76.4 \mathrm{ka} \mathrm{BP}$ should also be a concrete manifestation of this tectonic movement.

\section{DATA AVAILABILITY STATEMENT}

The original contributions presented in the study are included in the article/Supplementary Material, further inquiries can be directed to the corresponding authors.

\section{AUTHOR CONTRIBUTIONS}

The overall idea of this article was provided by XX. The article was mainly written by LB. The filed investigation was finished by LB, HL and KL. The samples analyzed were mainly finsihed by LB and JZ. And all the authors were participated in the discussion.

\section{FUNDING}

This study is supported by the Nation Science Foundation of China (Grant numbers 91214201), and Research projects in earthquake industry, China (Grant numbers 201508010). The 14C samples were analyzed at Beta Analytic Radiocarbon Dating Laboratory, United States. The OSL samples were analyzed by JZ at Key Laboratory of Crustal Dynamics, National Institute of Natural Hazards. The ESR samples were analyzed at Electron Spin Resonance Dating Laboratory at the Key Laboratory of Earthquake Dynamics, Institute of Geology, China Earthquake Administration.

\section{ACKNOWLEDGMENTS}

We are grateful to Yang Haibo for helpful discussion. We also thank the reviewers and the editor for their help improving the manuscript.
Aitken, M. J. (1976). Thermoluminescent age evaluation and assessment of error limits: revised system. Archaeometry, 18 (2), 233-238. doi:10.1111/j.1475-4754. 1976.tb00168.x

Aitken, M. J. (1998). An introduction to optical dating, Oxford, United Kingdom: Oxford University Press, 39-50. 
Ali, M. Y., and Farid, A. (2016). Cretaceous - neogene structural evolution of Se Abu Dhabi, United Arab Emirates. J. Pet. Geology., 39 (3), 221-245. doi:10. $1111 /$ jpg. 12644

Cai, M. T., Ye, P. S., Yang, X. C., Zhang, X. J., Li, C. L., Zhou, W., et al. (2018). Evolution of sedimentary environment in the north hetao basin since $344 \mathrm{ka}$. J. Geomechanics. 24 (2), 253-262. doi:10.12090/j.issn.1006-6616.2018.24.02.027

Chadin, T. D., and Licent, E. (1924). On the discovery of a paleolithic industry in northern China. Bull. Geol. Soc. China 3 (1), 45-50.

Cheng, S. P., Deng, Q. D., Min, W., and Yang, G. Z. (1998). Yellow River and quaternary tectonic movements of the ordos plateau. Quat. Sci. 18 (3), 238-248.

Cheng, S. P., Deng, Q. D., Yang, G. Z., and Ren, D. W. (2000). On the Cenozoic denudation and uplift of the daqingshan mountains, nei monggol. Seismology Geology 22 (1), 27-36.

Cui, D. X., Hao, M., Li, Y. H., Wang, W. P., Qin, S. L., and Li, C. J. (2016). Presentday crustal movement and strain of the surrounding area of ordos block derived from repeated GPS observations. Chin. J. Geophys., 59 (10), 3646-3661. doi:10. 6038/cjg20161012

Deng, Q. D., Zhang, P. Z., Ran, Y. K., Yang, X. P., Min, W., and Chu, Q. Z. (2002). Basic characteristics of active tectonics of China. Sci. China (Series D: Earth Sciences), 32 (12), 1020-1030.

Gaudemer, Y., Tapponnier, P., Meyer, B., Peltzer, G., Shunmin, G., Zhitai, C., et al. (1995). Partitioning of crustal slip between linked, active faults in the eastern qilian Shan, and evidence for a major seismic gap, the "Tianzhu gap," on the western haiyuan fault, gansu (China). Geophys. J. Int. 120 (3), 599-645. doi:10. 1111/j.1365-246x.1995.tb01842.x

Griffin, W. L., Andi, Z., O'Reilly, S. Y., and Ryan, C. G. (1998). Phanerozoic evolution of the lithosphere beneath the sino-Korean craton. Mantle Dyn. Plate Interactions East Asia,Geodynamics Ser. 107-126. doi:10.1029/ gd027p0107

He, B. Z., Xu, Z. Q., Jiao, C. L., Li, H. B., and Cai, Z. H. (2011). Tectonic unconformities and their forming: implication for hydrocarbon accumulations in tarim basin. Acta Petrologica Sinica, 27 (1), 253-265.

He, B. Z., Jiao, C. L., Xu, Z. Q., Cai, Z. H., Liu, S. L., Zhang, J. X., et al. (2015). Distribution and migration of the phanerozoic palaeo-uplifts in the tarim basin, NW China. Earth Sci. Front., 22 (3), 277-289.

He, D. F. (2007). Structure of unconformity and its control on hydrocarbon accumulation. Pet. Exploration Dev., 34 (2), 142-148.

He, L. (2015). Thermal regime of the north China craton: implications for craton destruction. Earth-Sci. Rev. 140, 14-26. doi:10.1016/j.earscirev.2014.10.011

$\mathrm{He}, \mathrm{Z}$., and Ma, B. (2015). Holocene paleoearthquakes of the daqingshan fault detected from knickpoint identification and alluvial soil profile. J. Asian Earth Sci. 98, 261-271. doi:10.1016/j.jseaes.2014.11.025

He, Z., Ma, B., Long, J., Zhang, H., Liang, K., and Jiang, D. (2017). Recent ground fissures in the hetao basin, inner Mongolia, China. Geomorphology, 295, 102-114. doi:10.1016/j.geomorph.2017.07.008

Hicks, N., and Green, A. (2017). A Mid-Miocene erosional unconformity from the durban basin, SE African margin: a combination of global eustatic sea level change, epeirogenic uplift, and ocean current initiation. Mar. Pet. Geology. 86, 798-811. doi:10.1016/j.marpetgeo.2017.06.037

Jia, L., Zhang, X., He, Z., He, X., Wu, F., Zhou, Y., et al. (2015). Late quaternary climatic and tectonic mechanisms driving river terrace development in an area of mountain uplift: a case study in the langshan area, inner Mongolia, northern China. Geomorphology, 234, 109-121. doi:10.1016/j.geomorph.2014.12.043

Jia, L., Zhang, X., Ye, P., Zhao, X., He, Z., He, X., et al. (2016). Development of the alluvial and lacustrine terraces on the northern margin of the Hetao Basin, inner Mongolia, China: implications for the evolution of the Yellow River in the hetao area since the late pleistocene. Geomorphology, 263, 87-98. doi:10.1016/j. geomorph.2016.03.034

Jiang, F. C., Fu, J. L., Wang, S. B., and Li, C. Z. (2013). Discussion on the epoch of lacustrine strata in togtoh, Inner Mongola, 19 (1), 1-13.

Jiang, W. L., and Zhang, Y. L. (1997). Characteristics of NW trending surface fractures of strong earthquakes and activity of the holocene faults of the boundary of north China plain. Earthquake Res. China, 13 (3), 263-270.

Li, J. J., Fang, X. M., Ma, H. Z., Zhu, J. J., Pan, B. T., and Chen, H. L. (1996). Geomorphological and environmental evolution in the upper reaches of the Yellow River during the late cenozoic. Sci. China Ser. D-earth Sci. 39 (4), 380-390.
Li, B. S., Jin, H. L., Zhu, Y. Z., Zhang, Y. H., Dong, G. R., and Sun, D. H. (2001). Recent study on the "ideal section in the southeast corner of ordos". J. Desert Res. 21 (4), 346-353.

Li, J. B., Ran, Y. K., and Guo, W. S., (2007). Division of quaternary beds and environment evolution in Hubao basin in China. Quat. Sci. 27, 632-644.

Li, B., Sun, D., Xu, W., Wang, F., Liang, B., Ma, Z., et al. (2017). Paleomagnetic chronology and paleoenvironmental records from drill cores from the Hetao Basin and their implications for the formation of the hobq desert and the Yellow River. Quat. Sci. Rev. 156, 69-89. doi:10.1016/j.quascirev.2016.11.023

Lin, C. S., Yang, C. J., Liu, J. Y., Cai, Z. Z., Peng, L., Yang, X. F., et al. (2008). Paleohigh geomorphology and paleogeographic framework and their controls on the formation and distribution of stratigraphic traps in the tarim basin. Oil \& Gas Grology, 29 (2), 189-197.

Lin, X. D., Yuan, H. Y., Xu, P., Yang, X., Xu, Z. G., Sun, H. X., et al. (2017). Zonational characteristics of earthquake focal mechanism solutions in North China. Chin. J. Geophys. 60 (12), 4589-4622.

Liu, H., Somerville, I. D., Lin, C., and Zuo, S. (2016). Distribution of palaeozoic tectonic superimposed unconformities in the Tarim Basin, NW China: significance for the evolution of palaeogeomorphology and sedimentary response. Geol. J., 51 (4), 627-651. doi:10.1002/gj.2664

Liu, M., Cui, X. J., and Liu, F. T. (2004). Cenozoic rifting and volcanism in eastern China: a mantle dynamic link to the Indo-Asian collision? Tectonophysics, 393 (1-4), 29-42. doi:10.1016/j.tecto.2004.07.029

Lu, H. Y., An, Z. S., Wang, X. Y., Tan, H. B., Zhu, R. X., Ma, H. Z., et al. (2004). The physiognomy evidence of periodic uplift in recent $14 \mathrm{Ma}$ in northeast of the qinghai-tibet plateau. Sci. China (Ser D), 34 (9), 855-864.

Lu, Y. C., Wang, X. L., and Wintle, A. G. (2007). A new OSL chronology for dust accumulation in the last 130,000 yr for the Chinese loess plateau, Quat. Res. 67, 152-160. doi:10.1016/j.yqres.2006.08.003

Luo, K. L., Li, B. S., Zhu, Y. Z., and Jin, H. L. (2002). Calcium carbonate cycles in salawusu river valley since $150 \mathrm{ka}$ B.P. Acta Geographica Sinica. 22 (6), 683-688.

Menzies, M. A., and Xu, Y. (1998). Geodynamics of the north China craton. 27: 155-165. doi:10.1029/gd027p0155

Middleton, T. A., Walker, R. T., Rood, D. H., Rhodes, E. J., Parsons, B., Lei, Q., et al. (2016). The tectonics of the western ordos plateau, ningxia, China: slip rates on the luoshan and east helanshan faults. Tectonics, 35 (11-12), 2754-2777. doi:10. $1002 / 2016 \mathrm{tc} 004230$

Min, L. R., Chi, Z. Q., and Zhu, G. X. (2000). Division of quaternary lacustrine beds in jinerwa bolehole of the yangyuan basin. Acta Geographica Sinica, 74 (2), $108-115$.

Min, L. R., Zhang, Z. Y., Wang, X. S., Zheng, S. H., and Zhu, G. X. (2006). The basal boundary of the nihewan formation at the taierwan section of yangyuan, hebei province. J. Stratigr. 30 (2), 103-108.

Murray, A. S., and Wintle, A. G. (2000). Luminescence dating of quartz using an improved single-aliquot regenerative-dose protocol. Radiat. Measurements, 32(1), 57-73. doi:10.1016/s1350-4487(99)00253-x

Murray, A. S., and Wintle, A. G. (2003). The single aliquot regenerative dose protocol: potential for improvements in reliability. Radiat. Measurements, 37 (4-5), 377-381. doi:10.1016/s1350-4487(03)00053-2

Northrup, C. J., Royden, L. H., and Burchfiel, B. C. (1995). Motion of the Pacific plate relative to eurasia and its potential relation to cenozoic extension along the eastern margin of eurasia. Geol., 23 (8), 719-722. doi:10.1130/0091-7613(1995) 023<0719:motppr>2.3.co;2

Peltzer, G., Tapponnier, P., Zhitao, Z., and Qin, X. Z. (1985). Neogene and quaternary faulting in and along the qinling Shan. Nature, 317 (6037), 500-505. doi:10.1038/317500a0

Ran, Y. K., Zhang, P. Z., and Chen, L. C. (2003). Research on the completeness of paleoseismic activity history since late quaternary along the Daqingshan piedmont fault in hetao depression zone, North China. Earth Sci. Front. 10 (S1), 207-216.

Ren, J. Y., Tamaki, K., Li, S. T., and Zhang, J. X. (2002). Late Mesozoic and Cenozoic rifting and its dynamic setting in Eastern China and adjacent areas. Tectonophysics, 344 (3-4), 175-205. doi:10.1016/s0040-1951(01)00271-2

Schellart, W. P., and Lister, G. S. (2005). The role of the East Asian active margin in widespread extensional and strike-slip deformation in East Asia. J. Geol. Soc. 162 (6), 959-972. doi:10.1144/0016-764904-112

Shackleton, N. J., Imbrie, J., and Hall, M. A. (1983). Oxygen and carbon isotope record of East Pacific core V19-30: implications for the formation of deep water 
in the late pleistocene North Atlantic. Earth Planet. Sci. Lett. 65 (2), 233-244. doi:10.1016/0012-821x(83)90162-0

Shi, W., Dong, S., and Hu, J. (2020). Neotectonics around the ordos block, North China: a review and new insights. Earth-science Rev. 200, 102969. doi:10.1016/j. earscirev.2019.102969

Su, Z. Z., Dong, G. R., and Jin, H. L. (1997). A geochronological study of the salawusu strata in North China. J. Geomechanics. 3 (4), 92-98.

Sun, J. M., Ding, Z. L., Yuan, B. Y., and Liu, D. S. (1996). Stratigraphic division of the sala Us formation and the inferred sedimentary environment. Mar. Geology. Quat. Geology. 16 (1):23-31.

Tapponnier, P., Peltzer, G., Le Dain, A. Y., Armijo, R., and Cobbold, P. (1982). Propagating extrusion tectonics in Asia: new insights from simple experiments with plasticine. Geol, 10 (12), 611-616. doi:10.1130/0091-7613(1982)10<611: petian>2.0.co;2

The Research Group on Active Fault System around Ordos Massif, State Seismological Bureau (RGAFSO), (1988). Active fault system Around Ordos Massif, Beijing, China: Seismological Press. 1-335.

Tian, Q. J., Shen, X. H., Feng, X. J., and Wei, K. B. (2003). Primary study on quaternary tectonic events based on variation of fault activity in Weihe Basin. Seismology Geology., 25 (1), 146-154.

Tian, Z. Y., Han, P., and Xu, K. D. (1992). The Mesozoic-Cenozoic East China rift system. Tectonophysics, 208 (1-3), 341-363. doi:10.1016/0040-1951(92) 90354-9

Tong, G. B., Shi, Y., Fan, S. X., Zhang, J. P., Song, X. H., Liu, Z. X., et al. (1995). Environment features of yinchuan basin in late quaternary period. Earth Science-Journal China Univ. Geosciences. 20(4), 421-426.

Tong, G. B., Shi, Y., Zhang, J. X., Zhang, X. H., Liu, Z. X., Lin, F., et al. (1998). Quarternary stratigraphy in yinchuan basin. J. Stratigr. 20 (4), $421-426$.

Uyeda, S., and Kanamori, H. (1979). Back-arc opening and the mode of subduction. J. Geophys. Res. 84 (B3), 1049-1061. doi:10.1029/jb084ib03p01049

Wan, T. F., and Cao, R. P. (1992). Mesozoic-early pleistocene tectonic events and stress fields in China. Geoscience, 6 (3), 275-284.

Wan, T. F. (1994). Tectonic event and stress field of quaternary in China. Quat. Sci. 14 (1), 48-55.

Wan, T. F. (2011). A discussion on the collision time. Earth Sci. Front. 18, 48-56.

Wang, X. L., Lu, Y. C., and Li, X. N. (2005). Luminescence dating of fine-grained quartz in Chinese loess simplified multiple aliquot regenerative dose (MAR) protocol. Seismology Geology. 04, 615-623.

Wu, F. Y., Lin, J. Q., Wilde, S. A., and Yang, J. H. (2005). NatuSe and significance of the Early Cretaceous giant igneous event in eastern China. Earth Planet. Sci. Lett. 233 (1-2), 103-119. doi:10.1016/j.epsl.2005.02.019

Wu, F. Y., Xu, Y. G., Gao, S., and Zheng, J. P. (2008). Lithospheric thinning and destruction of the north China carton. Acta Petrologica Sinica, 24 (6), 1145-1174. doi:10.1007/s10114-007-6354-y

Wu, W. M., Li, K., Ma, B. Q., Sheng, X. Q., Yang, D., Guo, W. S., et al. (1996). Study on the late quaternary slip rate of the piedmont fault of Mt. Daqingshan. institute of crustal dynamics, China earthquake administration. Beijing, China: Bulletin of the Institute of Crustal Dynamics: 1-10.

$\mathrm{Wu}, \mathrm{Z}$. H., and Wu, Z. H. (2003). Uplift history of the daqingshan mountain since the late cretaceous. Acta Geoscientia Sinica, 24(3), 205-210.

Xu, X., Ma, X., and Deng, Q. (1993). Neotectonic activity along the shanxi rift system, China. Tectonophysics, 219 (4), 305-325. doi:10.1016/0040-1951(93) 90180-r

Xu, X. W., and Ma, X. Y. (1992). Geodynamics of the shanxi rift system, China. Tectonophysics, 208 (1-3), 325-340. doi:10.1016/0040-1951(92)90353-8
Xu, X. W., Yu, G. H., and Ran, Y. K. (2015). Introduction to fault activity in the urban region, China-results from active fault's survey and detection in 20 cities, Beijing, China: Seismological Press, 484.

Yang, Z. J., Tong, G. B., Liu, Z. M., Xu, J. M., and Yang, X. L. (2001). Pollen assemblagesand paleoenvironment changes in yinchuan basin since midpleistocene. Acta Geographica Sinica, 22 (4), 369-374.

Yang, X., Cai, M., Ye, P., Yang, Y., Wu, Z., Zhou, Q., et al. (2018). Late Pleistocene paleolake evolution in the hetao basin, inner Mongolia, China. Quat. Int. 464, 386-395. doi:10.1016/j.quaint.2017.11.047

Yang, X. C., Cai, M. T., Hu, J. M., Ye, P. S., Ji, F. B., Zhang, Z. G., et al. (2020). The paleolake hydrology and climate change since the $\sim 40 \mathrm{ka}$ in the hetao basin, inner Mongolia, China. Quat. Int. 553, 73-82.

Yao, T. D. (1999). Tibetan Plateau abrupt climate change during the last glaciation: a comparative study on guliya ice core and Greenland GRIP ice core. Sci. Chin. (Ser. D), 29 (2), 175-184.

Yin, A. (2010). Cenozoic tectonic evolution of Asia: a preliminary synthesis. Tectonophysics, 488 (1-4), 293-325. doi:10.1016/j.tecto.2009.06.002

Yuan, B. Y. (1978). Sedimentary environment and stratigraphical subdivision of sharaosso-gol formation. Scientia Geologica Sinica. 3 (32), 330.

Yuan, B. Y., Cui, Z. J., Zhu, R. X., Tian, W. L., and Li, R. Q. (1996). The age, stratigraphic division and correlation of Nihewan Formation. Sci. China 26, 63-73.

Zhang, Y. G., Zheng, W. J., Wang, Y. J., Zhang, D. L., Tian, Y. T., Wang, M., et al. (2018). Contemporary deformation of the North China plain from global positioning system data. Geophys. Res. Lett., 45 (4), 1851-1859. doi:10.1002/ 2017gl076599

Zhang, Y. H., Li, B. S., and Jin, H. L. (2001). Grain-size cycles in salawusu river valleysince 150Ka BP. Acta Geographica Sinica, 68(3), 332-344.

Zhang, Y. Q., Liao, C. Z., Shi, W., and Hu, B. (2006). Neotectonic evolution of the peripheral zones of the ordos basin and geodynamic setting. Geol. J. China Universities, 12 (3), 285-297.

Zhang, Y. Q., Mercier, J. L., and Vergély, P. (1998). Extension in the graben systems around the ordos (China), and its contribution to the extrusion tectonics of south China with respect to Gobi-Mongolia. Tectonophysics, 285 (1-2), 41-75. doi:10.1016/s0040-1951(97)00170-4

Zhang, Y. Q., Shi, W., and Dong, S. W. (2019). Neotectonics of North China: interplay between far-field effect of India-Eurasia collision and Pacific subduction related deep-seated mantle upwelling. Acta Geologica Sinica, 93 (5), 971-1001. doi:10.1111/1755-6724.13930

Zhu, R. X. (2018). Review of the Achievements of major research plan on "destruction of north China craton". China Sci. Found., 3, 282-290.

Zhu, R., and Zheng, T. (2009). Destruction geodynamics of the north China craton and its paleoproterozoic plate tectonics. Sci. Bull. 54 (19), 3354. doi:10.1007/ s11434-009-0451-5

Conflict of Interest: The authors declare that the research was conducted in the absence of any commercial or financial relationships that could be construed as a potential conflict of interest.

Copyright ( $2021 \mathrm{Bai}, \mathrm{Xu}, \mathrm{Luo}, \mathrm{Li}$, Tan and Zhao. This is an open-access article distributed under the terms of the Creative Commons Attribution License (CC BY). The use, distribution or reproduction in other forums is permitted, provided the original author(s) and the copyright owner(s) are credited and that the original publication in this journal is cited, in accordance with accepted academic practice. No use, distribution or reproduction is permitted which does not comply with these terms. 